\title{
2012 NEW HAMPSHIRE CIVIC HEALTH INDEX
}

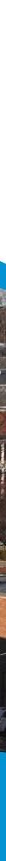

$M+5 \times 1$ 


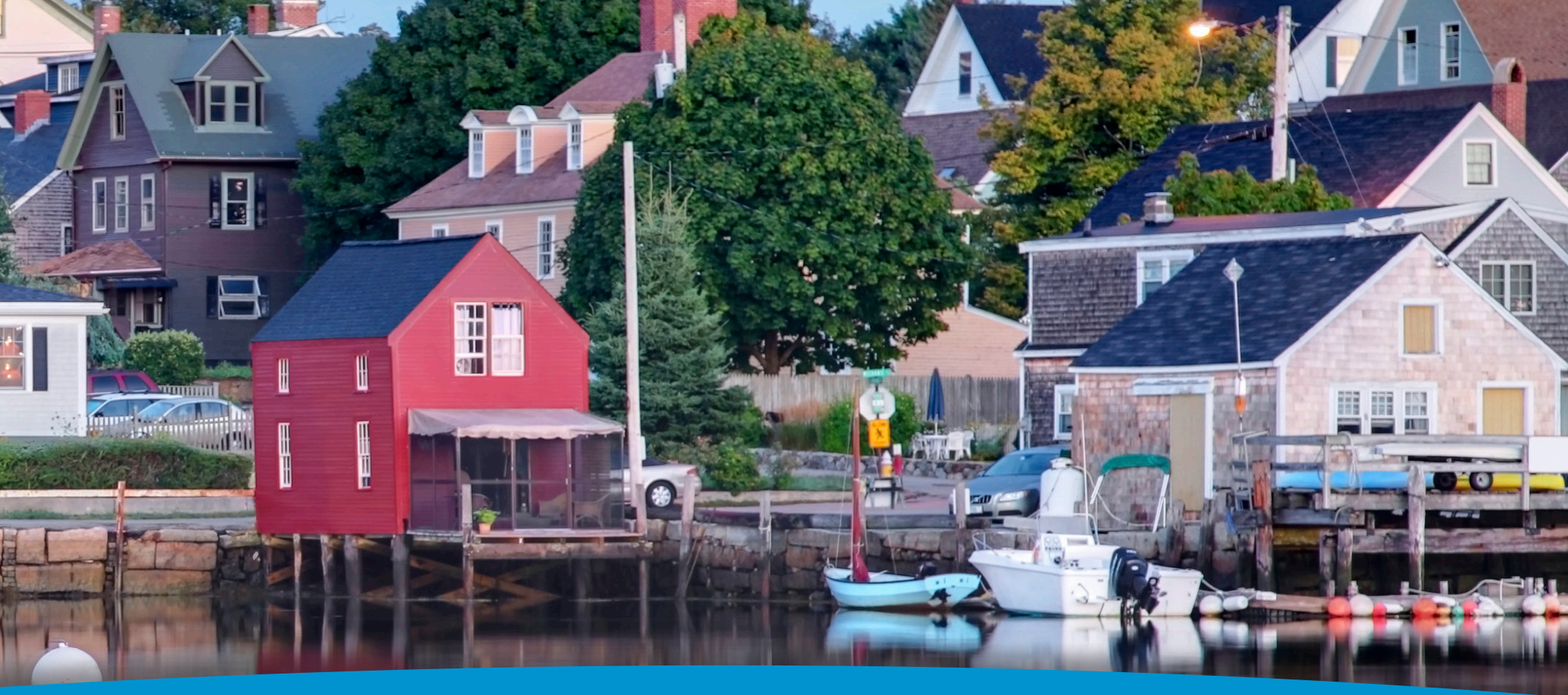

\section{ACKNOWLEDGEMENTS}

The authors thank Kristi Tate (NCoC) and Kei Kawashima-Ginsberg (CIRCLE) for their assistance with data analysis and editorial review. We are grateful for the extensive production assistance from Amy Sterndale (Carsey Institute) and Laurel Lloyd (Carsey Institute). A special thanks also to all our readers and reviewers for their helpful feedback, including Marybeth Mattingly, Mica Stark, Andy Smith, Malcolm Smith, and Debby Scire.

\section{About the Authors}

Bruce Mallory is the Carsey Institute's interim director and professor of education at the University of New Hampshire. Quixada Moore-Vissing is a PhD student in education at the University of New Hampshire and a graduate research assistant at the Carsey Institute. Both authors are part of NH Listens, the Carsey Institute's civic engagement initiative, which Mallory co-founded and directs.

\section{Partners}

The 2012 New Hampshire Civic Health Index was written by Bruce Mallory and Quixada MooreVissing at the University of New Hampshire's Carsey Institute with the assistance and financial support of the following partners:

\section{NCoC}

\section{CIRSLE}

$$
\text { ה }
$$

Campus Compact for New Hampshire
University System

of New Hampshire

\section{New Hampshire \\ College}

UNIVERSITY

Council

\section{WHAT'S INSIDE}

4 Introduction

6 Context of New Hampshire

122012 Civic Health Index Findings

18 Concluding Summary

19 Implications of the 2012 Civic Health Index

23 Technical Notes

24 Endnotes

26 Civic Health Index State and Local Partners

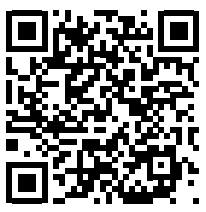

Use your smart phone to download the New Hampshire Civic Health Index 


\section{INTRODUCTION}

In 1991, the Governor's Commission on New Hampshire in the 21st Century, constituted and led by Governor Judd Gregg, published its final report following 18 months of broad-based deliberation with hundreds of civic, government, and business leaders. ${ }^{1}$ Five key principles were recommended by the Commission to guide the state into the next century. These principles captured the essence of New Hampshire's political, cultural, and social identity.

- To guide New Hampshire, we must invest in the people's capacity to govern.

- The people will preserve the landscape, and the landscape will renew the people.

- Change in New Hampshire comes from the community, not from some commission.

- A good idea that can be accomplished is worth dozens that can't.

- The best ideas have legs - they will move forward, having an impact decades from now.

What I love most about

New Hampshire is the all-hands-on-deck ethos of our people. Whenever there is a challenge, our people are ready to help and pitch in. We are a state that combines independence and community as nowhere else.

-Governor Maggie Hassan Inauguration speech

January 3, 2013
In most ways, these principles remain true and relevant some 22 years later. A strong belief in direct, participatory governance, close ties to the natural environment, local rather than state or federal authority, and devotion to pragmatism over all other "isms" are all reflected in the current civic health of New Hampshire. This is not to suggest that New Hampshire has not changed significantly over the past two decades - demographically, economically, even politically - but the core values that have characterized the state for many decades remain fundamentally in place. The following analysis of New Hampshire's civic health demonstrates that our communities and individual residents continue to believe that government works best at the local level, that volunteers play a central role in governance and civic life, and that practical solutions are perceived as more important and useful than ideological positions. The state motto, "Live Free or Die," while perhaps no longer as salient as it was when General John Stark first proclaimed it in 1809, still captures the basic sense of independence and autonomy that is found in our 234 municipalities.

\section{Defining Civic Health}

What does "civic health" mean? Civic health is distinct from, yet interconnected with, other forms of well-being, including physical and mental health and access to basic needs for food, shelter, and clothing. Civic health refers specifically to the ways in which residents of a community (or state) participate in civic activities that strengthen social capital, enhance interconnections, build trust, help each other, talk about public issues and challenges, volunteer in government and nonprofit organizations, stay informed about their communities, and participate directly in crafting solutions to various social and economic challenges.

\section{Report Overview}

The 2012 New Hampshire Civic Health Index follows earlier studies, including the New Hampshire Civic Index compiled by the NH Institute of Politics at Saint Anselm College in 2006 and the 2009 Civic Health Index published by the Carsey Institute in collaboration with the National Conference on Citizenship ( $\mathrm{NCoC}$ ) and Knowledge Networks. This report begins with key findings, a general description of the Granite State, followed by detailed findings from the U.S. Census Current Population Survey (CPS) and other surveys that illustrate patterns of volunteering and giving, voting and voter registration, civic engagement (both informal and formal), and confidence in public institutions (especially key in this Live Free or Die state). 
Other resources included in this report, listed on page 24, provide assessments of family and community well-being in New Hampshire, notably the NH Kids Count reports published regularly by the Children's Alliance of New Hampshire in partnership with the Carsey Institute. ${ }^{2}$ The New Hampshire Center for Public Policy Studies has also recently issued two important reports that provide valuable assessments of the state's social and economic landscape - From Tailwind to Headwind: New Hampshire's Shifting Economic Trends and What Is New Hampshire, 2012 edition. ${ }^{3}$ This report focuses on measurable indicators of civic health culled from responses of New Hampshire residents to the 2011 CPS Civic Engagement and Volunteer Supplements, 2010 CPS Voting and Registration Supplements, and other relevant surveys. Analysis of CPS data was provided by the Center for Information and Research on Civic Learning and Engagement (CIRCLE) at Tufts University, and detailed information on the data and sample can be found in the technical notes on page 23. More qualitative descriptions of how well communities function, how residents participate in decision-making, the tenor of public discourse, and how equitable participation is across social groups are outside of the scope of this report.

\section{Key Findings and Implications}

- New Hampshire citizens rank relatively high on several key indicators of civic health, including voter turnout in presidential election years and local elections, engaging in discussions of politics, attending public meetings, contacting public officials to express an opinion, and trusting their neighbors.

- New Hampshire residents see a relationship between educational attainment and economic conditions.

- High levels of educational attainment are associated with many of the key indicators of civic health such as volunteering and voting. New Hampshire should carefully consider threats and challenges to educational attainment in coming years.

- New Hampshire has weathered economic downturns better than states with lower levels of educational attainment. However, recovery from the Great Recession (the economic downturn that began in late 2007 and began sharp decline in September 2008) has been slower than in neighboring states. To maintain high levels of civic health, New Hampshire residents should turn attention to workforce development in coming years.

- New Hampshire has experienced more demographic change in recent years than in previous decades. Migration of new residents from other states has slowed considerably, which threatens New Hampshire's historical record of being one of the most highly educated states in the nation. Changing demographic composition and a decline in educational attainment could threaten New Hampshire residents' abilities to understand each other, trust each other, and solve community-based challenges.

- New Hampshire charitable giving increased from 53.7\% in 2008-2009 to 57.5\% in 2011. Though the state ranks last in the nation when it comes to the portion of income donated to charitable organizations, it still ranks 12 th in the nation in terms of the proportion of citizens who give over $\$ 25$.

- New Hampshire ranks 19th in the nation for volunteerism, with $29.4 \%$ of residents volunteering, compared with a national volunteerism rate of $26.8 \%$. Volunteer activity in the state has declined over the past decade, although there was some rebound in 2010-2011.

\section{2th}

New Hampshire's national rank in charitable giving of residents

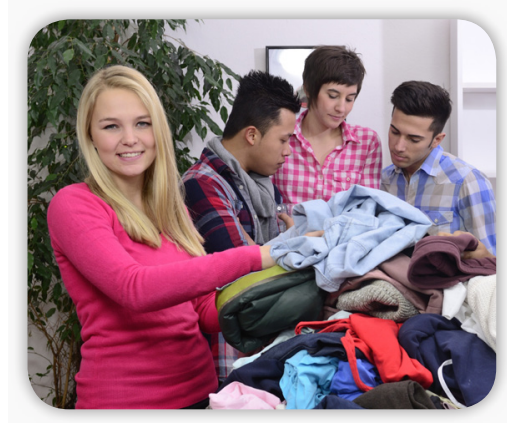




\section{CONTEXT OF NEW HAMPSHIRE}

\section{Population Growth and Composition}

\section{$1,300,000$}

2010 New Hampshire Population

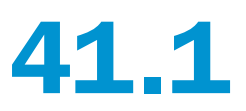

Median Age

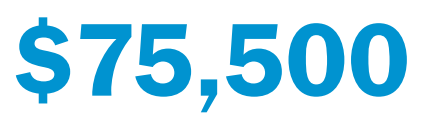

Median Family Income

\section{Foreign Born Residents}

\section{8}

$5.5 \%$

$12.8 \%$

- New Hampshire

United States

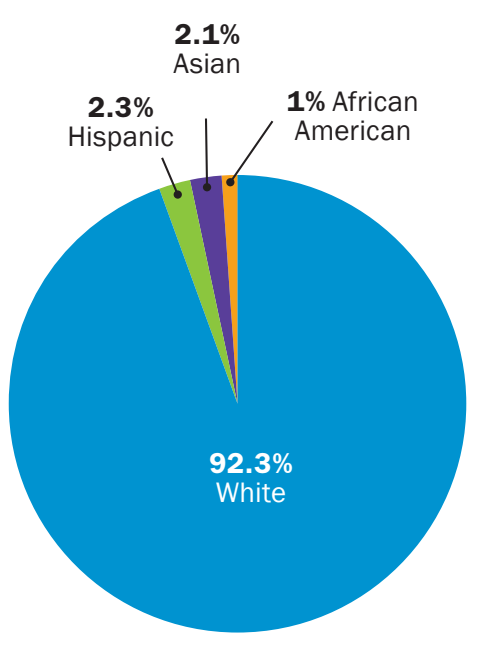

New Hampshire by Race
As of April 2010, New Hampshire's population was just over 1.3 million residents. The median age of these residents was 41.1 years, the $4^{\text {th }}$-highest median age in the country. Median family income was $\$ 75,500$, the $8^{\text {th }}$ highest in the country. The portion of residents with a college degree was roughly one-third ( $7^{\text {th }}$ highest in the country). Only 5.5\% of New Hampshire's residents were foreign-born, compared with $12.8 \%$ of the U.S. population. In 2010, 92.3\% of New Hampshire's population was non-Hispanic white, making the state one of the least ethnically diverse in the United States. Minorities represent $7.7 \%$ of the state's population. Hispanics, the largest group, numbered 36,700 (2.3\%); Asians follow at 28,200 (2.1\%), and Blacks at 13,600 (1.0\%). ${ }^{4}$ These aggregate statistics portray a state that is relatively wealthy, well-educated, white, and older.

Yet over the past ten years, New Hampshire has experienced significant demographic changes that are only understood by taking a closer, more nuanced look the numbers. Migrants into the state, rather than its native-born population, account for much of the high education and economic levels of the state population. Among New Hampshire adults age 25 and over, just 33\% were born in the state. Almost twice as many children belong to minority groups compared with adults (12.2\% vs. 6.3\%). As Carsey Institute Senior Demographic Ken Johnson has noted:

Concentrations of minority children are largest in the city of Manchester, where 30\% of children belong to a minority. Here, neighborhoods with significant concentrations of minority children are tightly clustered in the urban core. In a state where diversity historically has been unusual, such large concentrations of minority children represent a challenge to school districts, health care providers, and communities that must meet the needs of these diverse groups. It also presents an opportunity for these communities to embrace and celebrate diversity, as well as to use it to foster mutual understanding and acceptance. ${ }^{5}$

Much of Manchester's increased diversity in recent years is attributable to the arrival of new U.S. minority groups and immigrants from central and west Africa, southeast Asia, and eastern Europe (including a small number of refugees from countries that have experienced civil conflict and humanitarian disasters). The ethnic and linguistic diversity of Manchester (and increasingly in Nashua) is reflected in the scores of nationalities and foreign languages found in its public schools.

New Hampshire is often ranked as one of the best places to raise children. ${ }^{6}$ An overall child poverty rate of $12 \%$ in 2011 , the lowest in the country, was about half the national average, yet the number of poor children has been increasing by 3 percentage points since 2005, comparable to the national increase of 4 percentage points in the same time period. ${ }^{7}$ Combined child and adult poverty rates vary considerably across the state, by a factor of two to three times greater in the northern tier of the state compared with southern areas, ranging from $4.5 \%$ in the Nashua region to $12.7 \%$ in the area "above the notches". ${ }^{8}$ Child poverty and poverty overall will be further discussed in the sections on Education on pages 8 and 9 and on Economic Conditions on page 10.

Similarly, a deeper understanding of our older population is important. The primary factor influencing the rising median age in New Hampshire is the "aging in place" of its residents; the reduced inflow of younger migrants to the state is also a factor. Fewer younger residents are moving into New Hampshire than was the case prior to 2000. In 2010, 13.5\% of New Hampshire's population was 65 or older, only slightly above the national rate of $13.0 \% .{ }^{9}$ New Hampshire doesn't have an unusually large proportion of seniors or an older population; instead its high median age is a function of its large concentration of baby boomers (individuals born 1946-1964). ${ }^{10}$

Only two states have a larger proportion of baby boomers. New Hampshire's median age rose from 30.2 in 1980 to 41.1 in 2010. The U.S. median was 37.2 in $2010 .{ }^{11}$ The combined effect of "aging in place" and senior migration leads to a prediction that the population aged 65 to 74 will double ${ }^{12}$ in the next twenty years, a phenomenon being referred to here as the "silver tsunami." 
Lastly, compared to other states, the percentage of New Hampshire's population residing in rural areas is disproportionately large. Some $38 \%$ of our residents live in non-metropolitan counties compared with just $16 \%$ nationally. New Hampshire is also unusual in that its rural population has increased at a higher rate than its urban population in recent years. Migration accounted for $86 \%$ of the population increase in rural New Hampshire over the past ten years, compared with just $16 \%$ in its metropolitan areas. ${ }^{13}$ These trends are associated with the growth and prosperity of selected areas in the state that are relatively rich in amenities such as outdoor recreation venues and preserved natural spaces that draw skiers, hikers, and hunters - as tourists as well as second-home owners and retirees.

\section{Structure of New Hampshire's Governance}

The highly local, participatory nature of civic governance in the Granite State is best illustrated in the structure of our New Hampshire General Court, which contains the fourth-largest representative body in the English-speaking world. Each of the 400 members of the lower house represents 3,291 residents (a ratio that would result in 99,000 members in the U.S. House of Representatives if it were applied at the national level). For the past quarter-century, roughly one-fifth of all representatives and senators have been women. ${ }^{14}$ The average age of House members is over 60 , and more than half are retired from their primary occupations. State senators and representatives earn a salary of $\$ 100$ a year during their two-year terms, an amount set by Constitutional amendment in 1889 that remains in place today (officers receive $\$ 125$ per year). Thus, public office at the state level is itself an act of volunteerism, a pattern that holds true at the municipal level as well.

Whether our focus is at the state level, in our larger cities (which are small compared to national standards), or in our smaller cities and rural towns, the themes of independence, autonomy, citizen governance, engagement, and pragmatism characterize the civic life of the Granite State. High levels of voter participation (associated with New Hampshire's continuing status as the "firstin-the-nation" presidential primary state), the historical and continuing phenomenon of annual town meetings in many smaller communities to set policy and budgets, ${ }^{15}$ small and decentralized public school districts, and a highly constrained role for state government (determined substantially by the absence of state sales or personal income taxes - the only state with neither revenue source) all play a crucial role in defining who we are and sustaining our civic character.

\section{Political Identity}

In an era of Red and Blue politics, New Hampshire might be seen as an exemplar of a "purple" state. In 2012, the plurality (38.9\%) of registered voters was undeclared (commonly referred to as independent); Republicans constituted $32.7 \%$ and Democrats $28.4 \%$ of registered voters. This distribution of party identity is reflected in New Hampshire's role as a "battleground state" in national elections, where the role of independents is key. ${ }^{16}$ Party control of state offices has been volatile in recent years, beginning with the 2006 elections when Democrats took majority positions in both houses of the New Hampshire General Court and the Governor's seat, the first time for Democratic majorities in both the legislative and executive branches since 1874. In 2008, when Barack Obama was elected president by $54.3 \%$ of New Hampshire voters, ${ }^{17}$ Democratic control at the state level was maintained and the U.S. Congressional delegation was entirely Democratic for the first time since 1955. In 2010, when Republican and Republican-aligned Tea Party candidates experienced victories nationally, Republicans regained control of both the New Hampshire House and Senate by large margins, and retook three of the four Congressional seats (although the popular, moderate Democratic governor was re-elected). As the New York Times put it when speaking of New Hampshire the day after the election, "No state swung more sharply toward the Democrats in the last few cycles, and none swung harder in the Republicans' direction on Tuesday." ${ }^{18}$ As a result of the 2010 election, Republicans held $73 \%$ of the House seats and $79 \%$ in the Senate. ${ }^{19}$ In 2012, President Obama won 52\% of the New Hampshire vote for his reelection, ${ }^{20}$ and both of the state's U.S. House seats were won by Democrats ${ }^{21}$ (neither U.S. Senate seat was up for reelection in 2012). New Hampshire is represented by one Republican and one Democrat in the Senate. ${ }^{22}$

\section{$38.9 \%$}

of New Hampshire registered voters do not identify as either Democrats or Republicans.

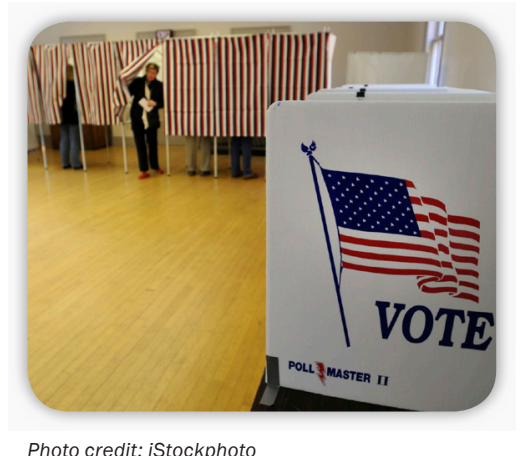

Photo credit: iStockphoto 
All this suggests that while there has been volatility in New Hampshire in recent years, state election results generally track national trends. There is movement around the center, with shifts in party control of the legislature, and there has been an increase in organized Free State, Tea Party, and associated liberty groups since 2008. The Free State Project, "an agreement among 20,000 pro-liberty activists..." who value "...the creation of a society in which the maximum role of government is the protection of life, liberty, and property..." selected New Hampshire as its "destination state" in 2003. ${ }^{23}$ The state was chosen because of its small size, lack of sales and income tax, less restrictive laws, and a "pro-liberty" political culture. ${ }^{24}$ Similarly, the New Hampshire Tea Party Coalition has been active in local and state elections and organizing its members to oppose government-sponsored initiatives related to sustainability and long-range planning, among other topics. While the liberty groups represent small numbers of individuals, they have played a role in the "Live Free or Die" political culture of the state, and have occasionally succeeded in gaining majority positions on a few local elected boards as well as playing a significant role in the 2010-2012 state legislature.

\section{Education and Youth}

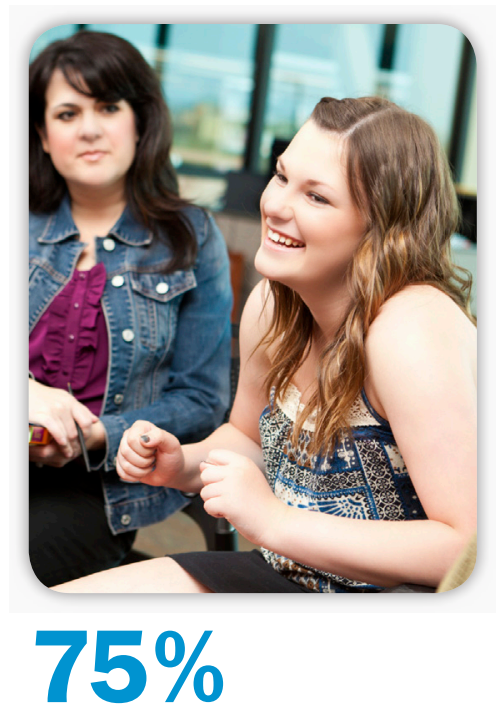

of all high school graduates entered into some form of post-secondary education.
We know that attainment of higher educational levels is associated with stronger civic health. This has been demonstrated in numerous civic health reports conducted in other states and holds true for New Hampshire. As NCoC points out, "People with higher levels of education are more likely to volunteer their time, vote, donate money, participate in a protest or a rally, lead civic associations and groups, join an organization, attend a meeting where political issues are discussed, contact or visit a public official, show support to a political party or candidate, and communicate with friends and family through email or the Internet..." Leaders of civic associations and community groups also come more frequently from the ranks of college graduates. Among Americans over age 24 with no college experience, only 3.5\% are leaders, compared to $13.5 \%$ of Americans with at least some college experience. An educated community is more likely to work for the common good. ${ }^{25}$ These national findings hold true in New Hampshire, as will be seen in the discussion of economic conditions on page 10.

\section{Post-Secondary Education in New Hampshire}

The portion of high school graduates who go on to post-secondary education is one measure of both the quality of K-12 education and the aspirations of our youth. In 2010 , about $75 \%$ of all high school graduates entered into some form of post-secondary education. Of these, $52 \%$ attended a two- or four-year college in New Hampshire (down from 57\% attending college in-state ten years earlier). ${ }^{26}$ As noted earlier, New Hampshire generally demonstrates a higher percentage of college-educated individuals than the rest of the nation. In 2010, 32\% of New Hampshire residents had a bachelor's degree compared with $28 \%$ nationally, ${ }^{27}$ and the state ranked 7 th in the nation for number of adult college graduates. ${ }^{28}$

However, rates of improvement in educational attainment in New Hampshire are slowing at a faster rate than in many parts of the country. ${ }^{29}$ Migration into the state, which is slowing, has traditionally been the source of many of our college-educated individuals. ${ }^{30}$ Thus, over time, New Hampshire's post-secondary education rates are predicted to fall if current trends are not reversed. The rising cost of college poses another potential threat to New Hampshire citizens' pursuit of post-secondary education. New Hampshire students have the highest student loan debt in the country, ${ }^{31}$ with an average debt of $\$ 32,440$ at graduation. ${ }^{32}$ Despite this debt, however, New Hampshire's student loan default rate is $5.1 \%$, indicating that the state's college graduates are some of the least likely in the nation to default on their loans. ${ }^{33}$

\section{K-12 Education in New Hampshire}

Reflecting the state's highly local political culture as well as its historically rural, non-urban living patterns, K-12 public education is structured around 94 Supervisory Administrative Units (SAUs), which are made up of 180 separate school districts. ${ }^{34}$ This highly decentralized structure 
is associated with considerable variability in educational quality and outcomes across the state. According to the New Hampshire Center for Public Policy Studies, the state ranks in the bottom third for state contributions to education when compared with the rest of the nation. ${ }^{35}$ Despite low state contributions to education, New Hampshire spends more per pupil than the national average, with an average contribution of $\$ 12,383$ per pupil compared with a national average of $\$ 10,165 .^{36}$ These levels of support vary considerably across the state. For example, in the city of Franklin in Merrimack County, per pupil expenditures were $307 \%$ higher than in the district of Errol in Coos County $(\$ 31,352$ vs. $\$ 9,647) .{ }^{37}$ It should be noted that both communities have average household incomes below the state average.

As previously discussed, although New Hampshire has the lowest child poverty rate in the country, ${ }^{38}$ some school districts reported as many as $86 \%$ of their students receiving free and reduced school lunch, and other schools had no students receiving free and reduced lunch. ${ }^{39}$ Though New Hampshire is ranked as first in the nation as the best place for child and family well-being, ${ }^{40}$ depending on where a child lives within the state, poverty rates and community levels of support for education vary greatly.

Young people in New Hampshire tend to drop out of high school at lower rates and attend college at higher rates than other states. The four-year cumulative drop-out rate for high school students statewide is $4.7 \%,{ }^{41}$ which is lower than national averages, ${ }^{42}$ though the Manchester school district has a drop-out rate of $11.3 \% .{ }^{43}$ In 2007, then-Governor Lynch persuaded the state legislature to raise the permissible drop-out age from 16 to 18. In 2011, the Republican majority House reduced the age back to 16 , but the Senate did not concur, so the compulsory attendance age remains at 18 .

The public safety of our communities influences how citizens connect with, engage, and trust one another. In the wake of the Newtown, Connecticut shootings of school-age children in late 2012, New Hampshire residents may question the safety of their school communities. According to the 2011 Youth Risk Survey (see Figure 1 below), New Hampshire students were less likely to carry a weapon such as a gun or knife to school (14.5\%) compared with students nationally (16.6\%). ${ }^{44}$ Of this total percentage, New Hampshire males (22.2\%) carried weapons at higher rates than New Hampshire females (6.0\%); however, this trend is in line with national breakdowns by gender. ${ }^{45}$ Granite State students were also less likely to have engaged in a physical fight compared with students in the United States overall (23.8\% vs. 32.8\%). Although most New Hampshire students were unlikely to avoid school because they felt unsafe (only 4.9\% reported feeling unsafe), New Hampshire students reported that they were more likely to have been bullied on school property than their national counterparts (25.3\% vs. $20.1 \%$ ). New Hampshire students were also more likely to have been bullied electronically than reported in national samples ( $21.6 \%$ vs. $16.2 \%) .{ }^{46}$ Compared with national averages, New Hampshire students were slightly less likely to contemplate (14.9\%) or attempt suicide (6.1\%); however, about a quarter of New Hampshire students reported feeling so sad or hopeless every day for almost two weeks that they had stopped doing useful activities. Just under half of New Hampshire students (49\%) felt they mattered to their community. ${ }^{47}$ That over half do not feel this way is cause for concern and may be predictive of less engagement when these young people get older, if they continue to lack a sense of agency and worth.

\section{Fig. 1: Youth Risk Survey Results, 2011}

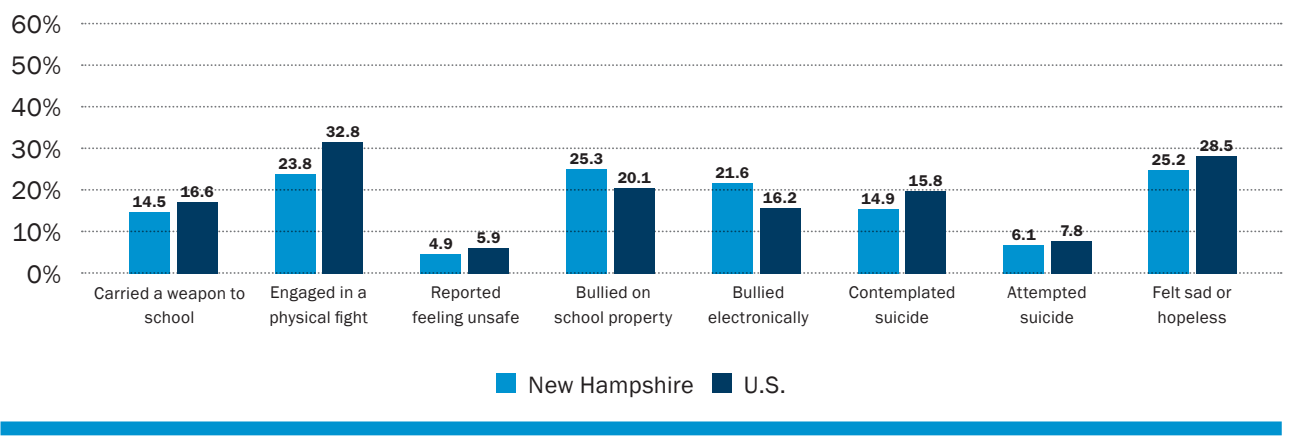

$4.7 \%$

Cumulative drop-out rate for high school students statewide, which is lower than the national average.

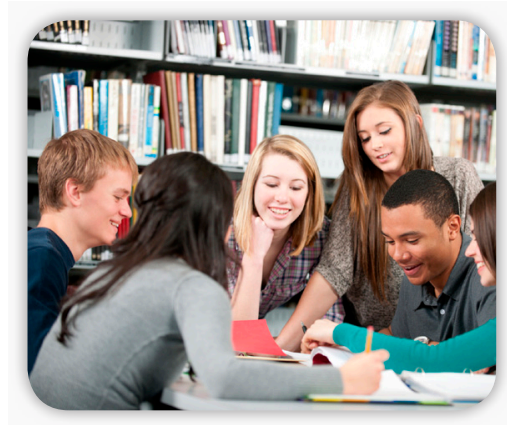




\section{Economic Conditions}

As with child poverty rankings, overall quality of life in New Hampshire ranks high compared with the rest of the nation. New Hampshire also has lower unemployment rates than the rest of the nation. As of November 2012, New Hampshire's unemployment rate was 5.6\%, compared with a national unemployment rate of $7.7 \%{ }^{48}$ However, New Hampshire still saw a small decrease of $0.6 \%$ in job availability from 2000 to $2010 .{ }^{49}$ In contrast, New Hampshire experienced job increases of $27.3 \%$ in the previous decade. ${ }^{50}$ Unemployment in the summer of 2012 was still nearly two percentage points higher than the pre-recession low. ${ }^{51}$ Continued ill effects of the recession are seen in New Hampshire's slow recovery. Though New Hampshire has historically had a strong economy, long-term predictions imply a slowing of the state's economy due to the drop in migration and consequent slow-down in population growth and labor productivity described earlier. ${ }^{52}$ New Hampshire has demonstrated a greater drop in Gross Domestic Product (GDP) growth from 1990 to 2000 than almost any other region of the country, and the state's GDP rate of growth has been slower than in any period in the past forty years. ${ }^{53}$

In recent reports published by the $\mathrm{NCOC}$ and partners, strong positive correlations have been found between civic engagement and lower unemployment rates. ${ }^{54}$ Specifically, states with higher rates of volunteering and civic engagement in 2006 showed smaller increases in unemployment through 2010, including New Hampshire. The most recent report was released in 2012 as an update to the 2011 report, Civic Health and Unemployment: Can Engagement Strengthen the Economy? It identifies two especially strong factors associated with civic health:

- States with high social cohesion had unemployment rates two percentage points lower than their less connected and trusting counterparts, even when controlling for demographics and economic factors. ("Social cohesion" is defined as trusting neighbors, talking to and helping neighbors, and socializing with family and friends.)

- A county with one extra nonprofit per 1,000 people in 2005 would have half a percentage point less unemployment by 2009 . For individuals who held jobs in 2008 , the odds of becoming unemployed were cut in half if they lived in a community with many nonprofit organizations rather than one with a few nonprofits, even if the two communities were otherwise similar. ${ }^{55}$

The authors of the report argue that "When civic health is higher, people seem to have more affection and optimism for their own communities and put more trust in their neighbors. When investors, employers, and consumers feel greater commitment to the places they live, they may be more likely to make economic decisions that generate or protect local jobs. Furthermore, being engaged with fellow citizens and participating with nonprofits can build local allegiance that makes individuals more likely to spend, invest, collaborate, and address problems in their own communities. These small choices can have ripple effects for a community's ability to remain strong during a crisis." The text box on page 11 suggests a number of ways in which employment opportunities are associated with strong civic health. 
If two cities or states face similar economic circumstances, the one with stronger civic life will weather the recession better. In 2011, NCoC and partners released Civic Health and Unemployment: Can Engagement Strengthen the Economy? which found that the following indicators were related to resilience against unemployment:

Working with neighbors on a community issue

- Attending public meetings

- Volunteering

- Registering to vote and voting

The report proposed six explanations for the connection between these civic health indicators and unemployment:

1. Human capital: Participation in civic society can help develop skills, confidence, and habits that make people employable.

2. Networks: People get jobs through social networks, including neighbors, service organizations, and community groups.

3. Information: Better information flow makes it easier to find jobs and employees, and for citizens to communicate with the government.

4. Trust: Trusting relationships are more likely to spread membership and information, and instill the confidence necessary to invest, hire, and build businesses.

5. Good Government: Communities with stronger civil societies are more likely to have good governments, which lead to higher performing schools, and inclusive public policies that affect unemployment and social services.

6. Attachment: Feelings of attachment to community increase the odds that one will invest, spend, and hire there.

Building upon this research, in 2012, NCoC and partners released a follow-up report that strengthened confidence in the connection between civic health and unemployment. The 2011 report found that, even more strongly than the above indicators, the density and type of nonprofit organizations in a community, as well as its social cohesion, are important predictors of that community's ability to withstand unemployment in a recession.

From Civic Health and Unemployment: Can Engagement Strengthen the Economy? (www.NCoC.net/unemployment) and Civic Health and Unemployment II: The Case Builds (www.NCoC.net/unemployment2).

\section{$21 \%$}

The rate of decline for New Hampshire residents' total volunteer hours over the past eight years

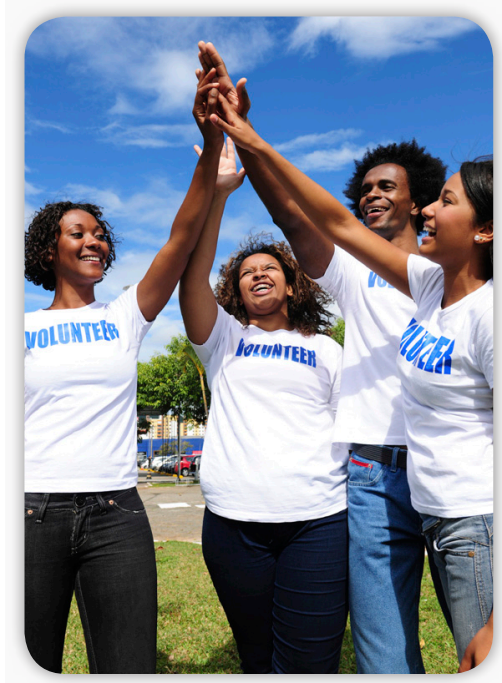




\section{CIVIC HEALTH INDEX FINDINGS}

\begin{abstract}
The sections above provide a context for understanding New Hampshire's overall social, educational, economic, and political characteristics. In the next sections, findings specific to civic health gleaned from the most recent CPS supplements on volunteering, civic engagement, and voting are presented in detail.
\end{abstract}

\section{Volunteering and Giving}

Consistent with Governor Hassan's inauguration comments on our independent and communityoriented values, New Hampshire residents volunteer their time somewhat more frequently than those in other states. In 2011, New Hampshire ranked 19th in the nation for residents who volunteer at least once a year. Of the $\mathrm{NH}$ residents surveyed, $29.4 \%$ or 314,000 indicated they had volunteered through or for an organization or in another venue such as a child's school (the national volunteering rate was 26.8\%). Volunteering in New Hampshire has declined since 2004, when the rate was 33.2\%. In general, volunteer activity declined by about 44,000 volunteers from 2004 to 2010 , with a rebound of some 19,000 volunteers between 2010 and $2011 .{ }^{56}$ Annual hours of volunteer time per resident in 2011 were 31.6, compared with the high of 41.8 hours per capita in 2004. ${ }^{57}$ Total volunteer hours in New Hampshire have declined by $21 \%$ over the past eight years. This trend is consistent with the national data, which also show similar declines in volunteering hours overall.

\section{Fig. 2: Volunteerism by Gender, Income, and Educational Attainment, 2011}

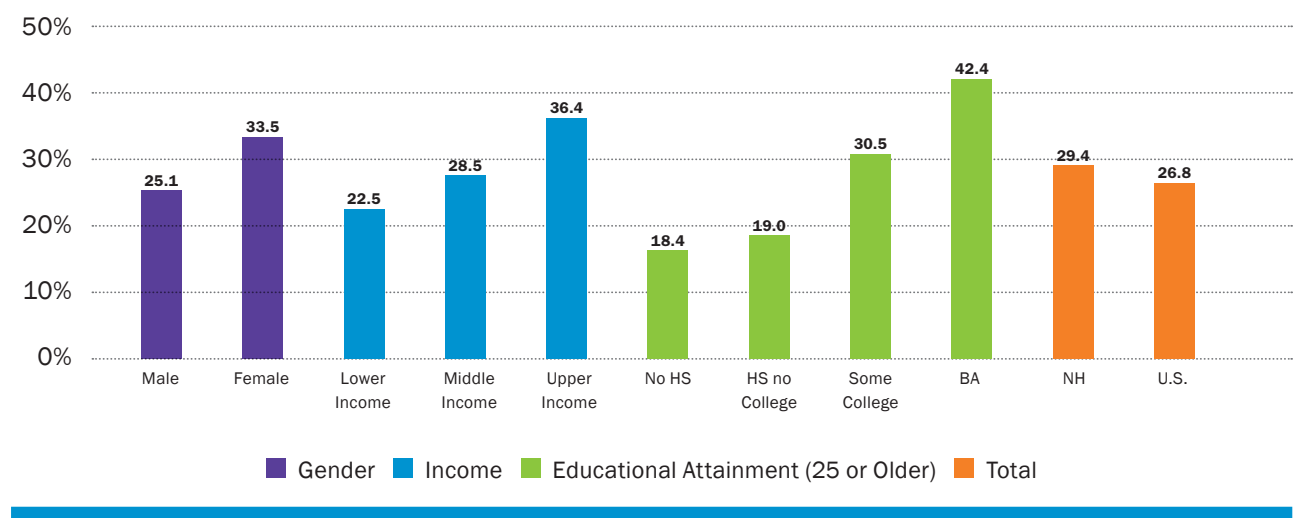

The rate at which one volunteers is directly correlated with gender, income, and education level. Figure 2 shows that women are more likely than men to volunteer, those with higher incomes volunteer more than those with lower incomes, ${ }^{58}$ and those who have completed college are more likely to volunteer than those who have not.

In spite of our generally secular nature (see page 13), residents are most likely to volunteer in educational settings (29.9\%), followed by religious organizations $(20.6 \%)$, social service organizations (16.4\%), health-related organizations (10.8\%), and civic clubs or organizations (for example, American Legion, Lions Club - 8.2\%). See Figure 3. Less frequent venues for volunteering include sports programs, arts and cultural activities, and miscellaneous other activities. The most frequent form of volunteering in 2011 was fundraising, followed by offering professional skills and expertise, collecting and/or distributing food, general labor, mentoring youth, tutoring or teaching, and a range of other less-frequent activities. Teenagers (16-19 years old) were highly likely to volunteer (32.3\%), probably because of school- or church-related service activities, while the next oldest age group, those between 20 and 24, were least likely (14.5\%). Volunteering peaks in the 
35-44 age group (34.7\%), with comparably high rates for those between 65- and 74-years-old (32.2\%). Urban and rural residents were more likely to volunteer (31.8\% and $31 \%$, respectively) than suburban residents (26.1\%). ${ }^{59}$

\section{Fig. 3: Volunteering, 2011}

2011 (ranking in parentheses)

\section{$26.8 \%$}

New Hampshire

United States

\section{Forms of volunteering:}

Fundraising $\mathbf{2 6 . 6 \%}$

Offering professional skills/expertise $\mathbf{1 8 . 9 \%}$

Collecting and/or distributing food $18.2 \%$

General labor

Mentoring youth

Tutoring or Teaching

Other
$17.9 \%$

$13 \%$

$12.4 \%$
$63.6 \%$

of residents vote always or sometimes in local elections compared with $57.7 \%$ nationally.

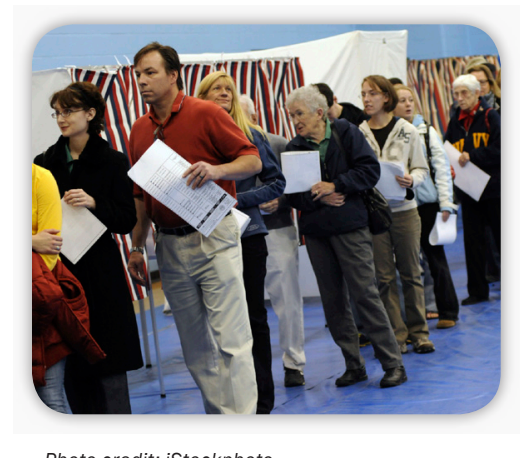

Photo credit: iStockphoto

ing the Granite State stereotype of caring but frugal neighbors). Similar to national trends, there has been a steady, modest decline in New Hampshire volunteer activity since 2004, but slight increases in volunteering occurred from 2008 to 2011. There is a higher degree of volunteering in civic and health-related organizations in New Hampshire than nationally, with lower rates of volunteering in education, religious, and social service organizations compared with national data.

\section{Religious Beliefs and Behaviors}

Residents of the New England region in general, and in New Hampshire in particular, are less religious than those in other parts of the United States. ${ }^{63}$ In the most recent Gallup Poll on religious beliefs, ${ }^{64}$ New Hampshire and its neighbor Vermont report the fewest residents who describe themselves as "very religious" (23\% each); over half (52\%) of New Hampshire's residents describe themselves as "nonreligious." A majority of New Hampshire residents (52\%) agree that "religion is not an important part of my daily life and I seldom or never attend religious services." In the general U.S. population, $40 \%$ of those surveyed were very religious, and only $32 \%$ reported they were nonreligious.

\section{Political Activity}

As indicated earlier, the largest number of registered voters in New Hampshire is independent, without a declared party affiliation. But this is hardly a sign of apathy, at least with respect to our role in national electoral politics. Voter turnout ${ }^{65}$ varies considerably across years, with high rates in presidential election years (2004, 79.9\%; 2008, 75\%; 2012, 79.3\%) and lower rates in mid-term elections (2006, 49.1\%; 2010, 48.8\%). ${ }^{66}$ See Figure 4. Two-thirds (66.5\%) of eligible New Hampshire voters were registered to vote in 2010 (ranked 22nd nationally). In presidential election years, New Hampshire ranks among the top three or four states in voter turnout in the 
general election. In mid-year elections, we rank only at the mid-point (e.g. 25th in 2010). When asked how often they vote in local elections, New Hampshire residents reported they vote in elections at a higher rate than their national counterparts $-63.6 \%$ of residents vote always or sometimes in local elections compared with $57.8 \%$ nationally. Fewer residents (27.7\%) never vote in local elections compared to those in other states (32.5\%). Given New Hampshire's frequent visits and attention by political candidates, it follows that voter turnout for local politics is above average when compared with the rest of the nation.

\section{Fig. 4: Voter Turnout, 2004-2012}

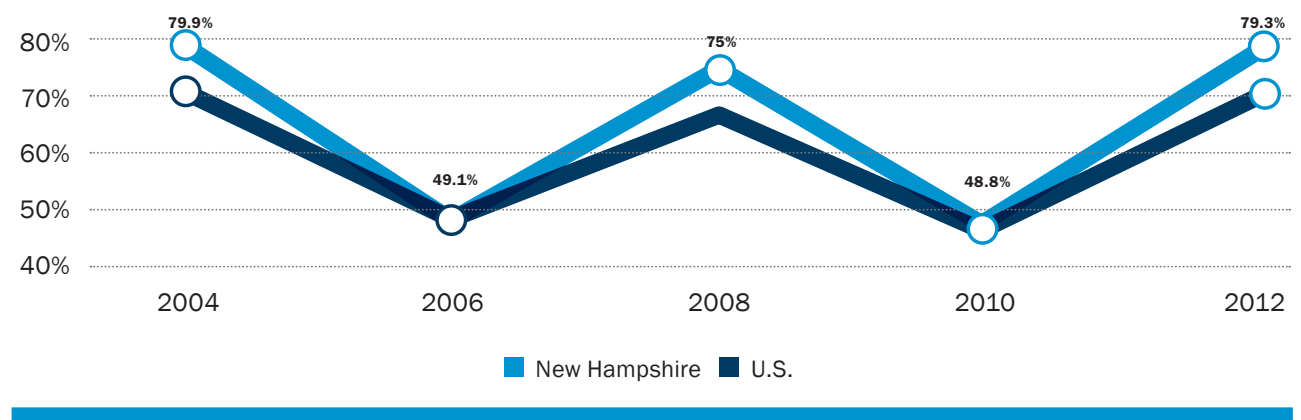

As with volunteering, gender, income, and education make a difference with respect to who votes in local elections. Figure 5 demonstrates these differences. New Hampshire women are more likely than men to vote "sometimes or always" in local elections; people with higher incomes and those with more education are also more likely to vote.

Fig. 5: Local Voting by Gender, Income, and Educational Attainment, 2011 (voting always or sometimes)

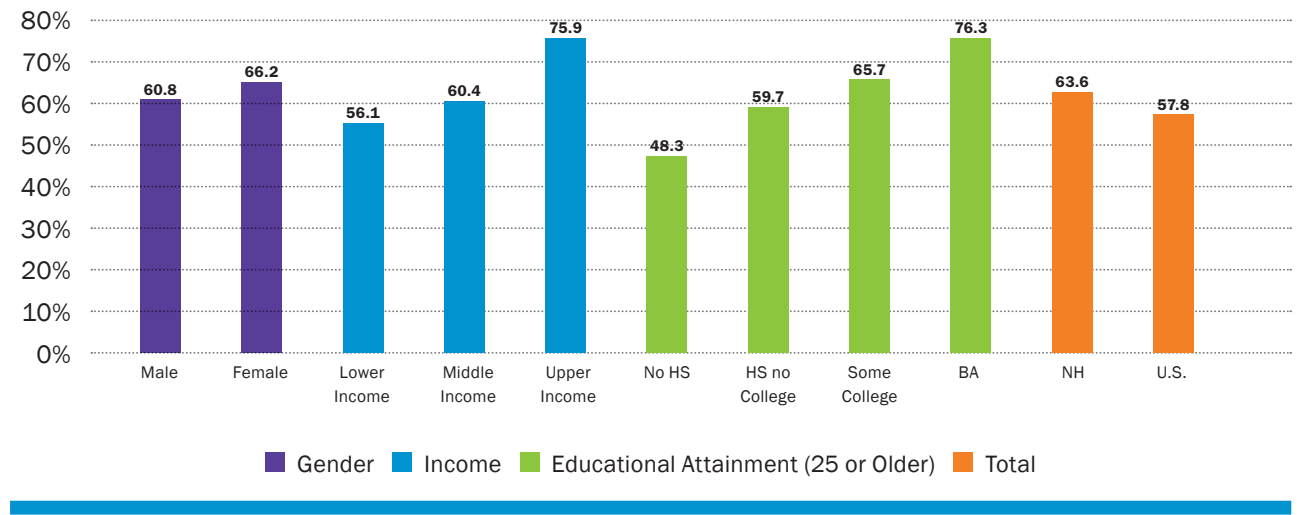

\section{Voting Trends}

While our local voting behavior generally mirrors national voting trends, New Hampshire residents talk about politics at rates above the national average. In 2011, CPS respondents in New Hampshire reported they discuss politics with friends on a daily or weekly basis at higher rates than those in other states (36.8\% compared with $29.3 \%$, ranking 6 th in the nation). This is also true with respect to use of the Internet to express or share political opinions (10.6\% in New Hampshire frequently do so, compared with $8.0 \%$ nationally). As seen in Figure 6 , talking about political issues with friends and family varies by gender, income, and education. Considering the question of who actually votes, it appears that men are more likely to talk about politics than women, and less likely than women to vote in local elections. 


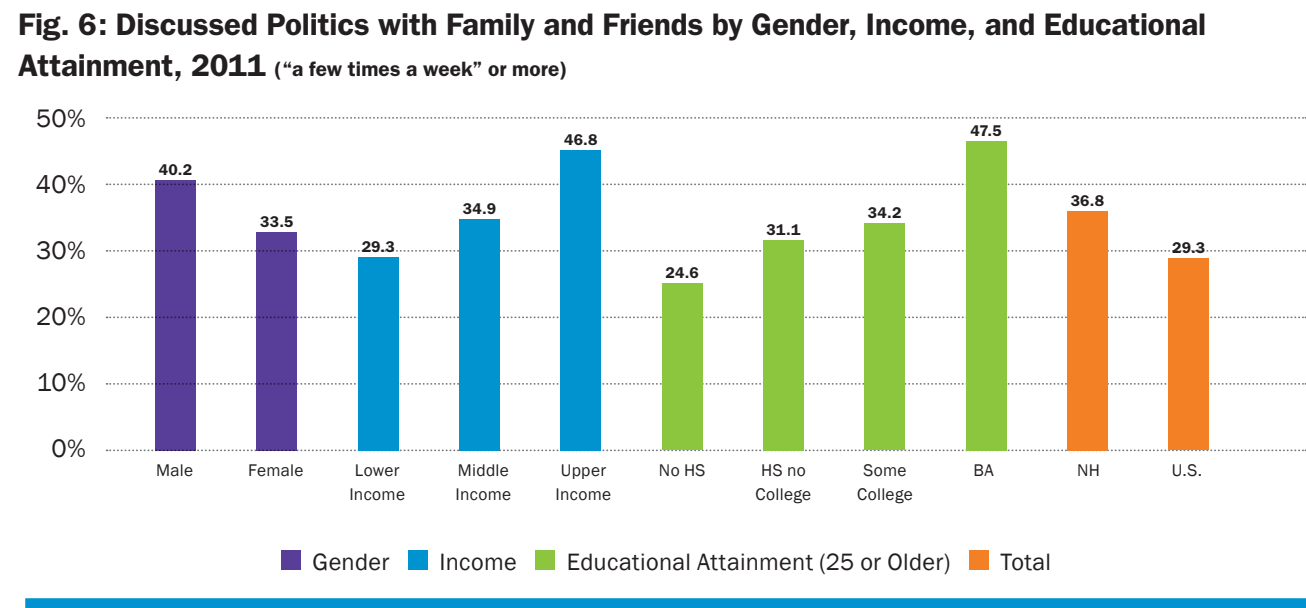

\section{Other Forms of Political Participation}

Other forms of political activity or participation also show relatively high levels of engagement. New Hampshire residents attend public meetings at a much higher rate than national averages $-16.3 \%$ of residents attended a public meeting in 2011, compared with $9.1 \%$ nationally (ranking New Hampshire 4th). We are more likely than many Americans to contact a public official to express an opinion (16.9\% vs. $12.3 \%$, ranked 13th). Those in higher income brackets and those with higher levels of education are much more likely to do so than others (see Fig. 7). We also are more likely to boycott a product because of our views about the social or political values of the company that provides it (15.6\% vs. $12.1 \%$, ranked 13 th). We are somewhat more likely to serve in volunteer leadership roles as an officer or committee member in an organization (12.7\% vs. $10.6 \%$, ranked 24th). Women serve in leadership roles at higher rates than men (15\% vs. 10.4\%); those with higher incomes (almost twice as many in the highest bracket than those in the lowest bracket) and those with a bachelor's degree (22.6\% vs. $12.6 \%$ for those with some college or $5 \%$ of those with only a high school diploma) are more likely to serve in leadership roles. Since individuals with higher incomes and levels of educational attainment are more likely to contact officials and take on community leadership positions, the voices of these individuals may exert a stronger force on community discourses and policy decisions than the voices of less represented groups.

Fig. 7: Contacted a Public Official Gender, Income, and Educational Attainment, 2011

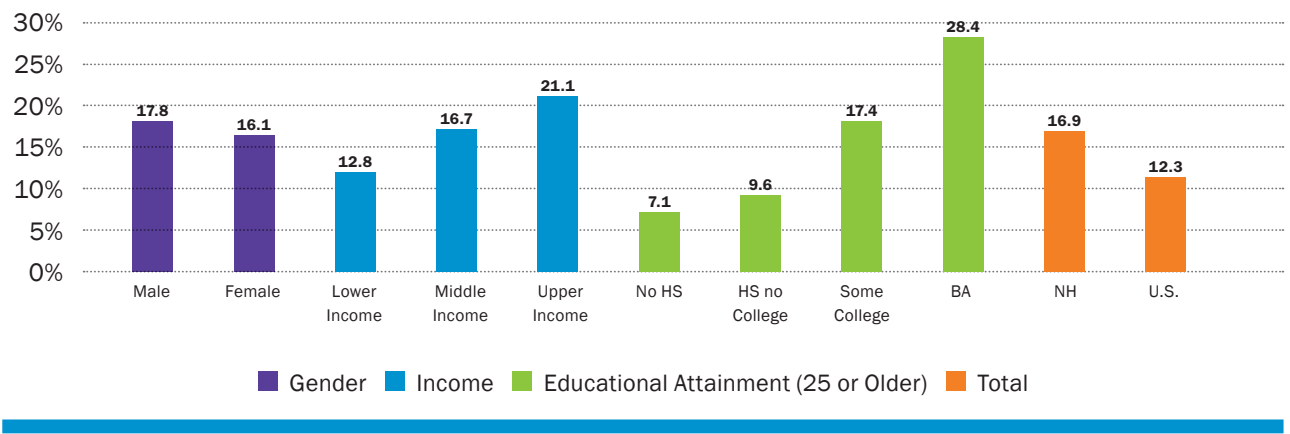

These data indicate that New Hampshire residents take their civic responsibilities seriously. Because the state continues to host the first presidential primary election every four years, our residents are exposed to considerable political activity, experience high quantities of media advertising and commentary pertaining to the elections, and often have multiple direct opportunities to interact with both mainstream candidates and those who represent more extreme or single-issue platforms. Recognizing that primary votes as well as those cast in the general election have been known to make or break candidacies, New Hampshire residents are proud of their role
42.7\%

of residents talk with neighbors daily or a few times a week.

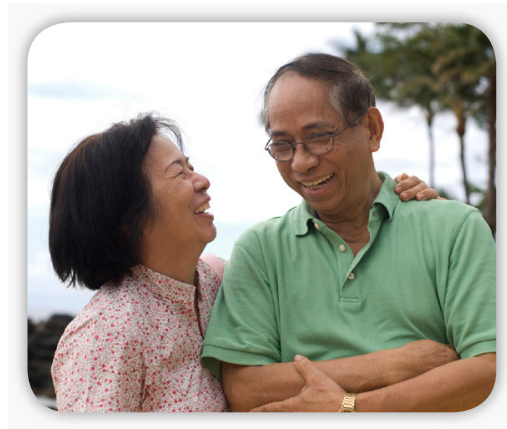


in national elections. Although New Hampshire residents generally vote at higher rates than their peers in other states, voting is only one means of political expression in the Granite State. New Hampshire residents seem more inclined than their national peers to engage directly in the life of politics, through informal discussions, participation in public meetings, and interactions with (or service as) community leaders. Most of this activity occurs at the "hyper-local" level, as seen by further examining the ways in which residents interact with family and neighbors, a fundamental ingredient of civic health. Thus, the health of political life in New Hampshire is multi-faceted.

\section{Community Engagement and Neighborliness}

One aspect of civic health is the degree to which residents interact with their neighbors in a variety of ways - by talking directly with them, doing favors for them, or participating in civic or religious organizations where they are likely to share time, opinions, meals, and volunteer projects together. New Hampshire residents do all these things relatively frequently, with participation rates comparable to their national peers. In terms of weekly interaction, a significant portion of residents surveyed $(42.7 \%)$ talk with neighbors daily or a few times a week (a rate that matches the national sample). Lower income residents were more likely to talk frequently (a few times a week or everyday) with neighbors or friends than those in middle and high income groups (50.8\%, $37.8 \%$, and $44 \%$, respectively). On a monthly basis, one-third of all New Hampshire residents report they do favors for their neighbors a few times a month or more (also comparable to the national sample). Interestingly, those in the lowest income brackets assist their neighbors at higher rates than those in the upper income brackets (36.8\% for the lowest group, $29.9 \%$ for the middle group, $36.3 \%$ for the highest group).

Those who were surveyed also reported levels of participation in service, civic, and sports or recreation groups at rates similar to their national peers (39\% of New Hampshire residents and $39.2 \%$ of the national sample). The one exception to this pattern was participation in religious organizations (measured separately from church attendance), with New Hampshire residents much less likely to belong to a religious organization (14.3\% compared with $20.6 \%$ nationally). This is consistent with the more secular nature of New Hampshire's population in general.

Participation in civic organizations, a key predictor of social capital and civic health, ${ }^{67}$ is affected by gender and income. Figure 8 shows significant differences between men and women (over a $2: 1$ ratio), and across income groups. The latter is not surprising; those individuals classified as low income may face a variety of challenges, including time, transportation, and childcare, which make participation in civic organizations simply less possible. Lower income individuals and those with less education are also less likely to act as leaders on committees or in groups, presumably due to a lack of resources and time. However, when it comes to strong relationships between neighbors, the data indicate lower income residents engage with neighbors at higher rates than their middle- and high-income peers. Building on this strong sense of neighborhood and neighborliness could be a vehicle for further engagement of low-income groups and individuals.

of residents eat dinner with family at least a few times per week.

\section{Fig. 8: Participation in a School Group, Neighborhood, or Community Association by Gender, Income, and Educational Attainment, 2011}

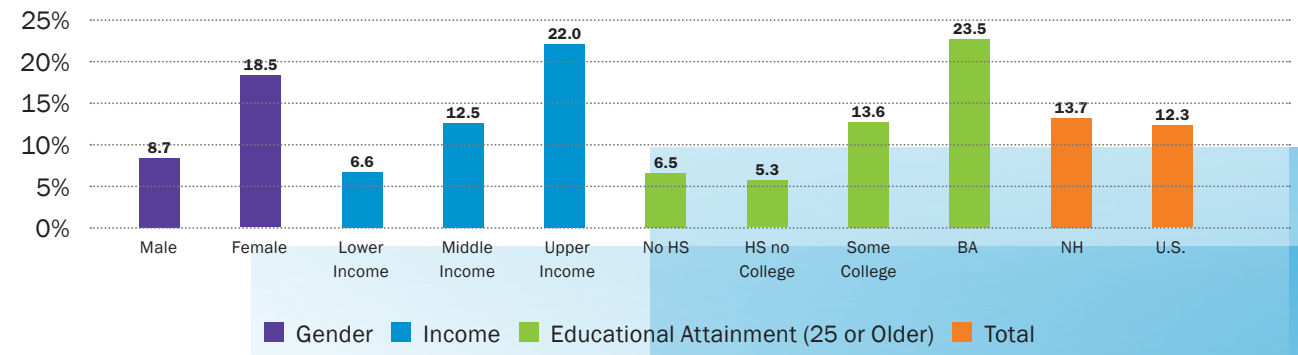


Time spent with friends or family is another key measure of civic health. The ties that bind us to friends and family are an important part of our social capital, and the nature of interactions with those close to us affects our ability to solve problems, fulfill our emotional and social needs, share resources, learn new skills, get advice, and so forth. Like our national peers, most of us eat dinner with household members at least a few times a week $(91.8 \%$ in New Hampshire and $89.5 \%$ nationally). We see or hear from family and friends at least a few times a week (79.9\% of New Hampshire residents and $79 \%$ nationally). These routine, informal activities have been cited as critical ingredients to the well-being of families and communities. ${ }^{68}$ Although New Hampshire is less diverse, less urban, and has higher levels of income and education than other states, these differences don't seem to matter with respect to how friends and family interact. CPS data from earlier surveys indicate that such activities may be increasing over time (about a five point increase between 2008 and 2011). In addition, survey responses indicate that New Hampshire residents are simply more likely to trust those who live in their neighborhoods than those who live in other states. When asked if they trust "most or all of the people in your neighborhood," $72.3 \%$ of New Hampshire residents said "yes," compared with $56.7 \%$ of the national sample. This would seem to bode well for continued civic health in New Hampshire in the coming years.

\section{Confidence in Public Institutions}

It is important that residents believe the institutions with which they most frequently interact are serving their intended purposes. We want our businesses, schools, and information media to operate in ways that are in the community's best interest and contributing to civic well-being (either through employment, philanthropic activity, or creating and disseminating services or knowledge useful to the public). New Hampshire residents have relatively high levels of confidence in corporations, similar to the national sample (about 65\% of those in New Hampshire report they have "some" or "a great deal" of confidence, compared with $62 \%$ nationally.) Likewise, New Hampshire residents have some or a great deal of confidence in the media $(62.5 \%$ vs. $62 \%$ nationally). Notably, we have especially high levels of confidence in our public schools (92.1\% have some or a great deal of confidence, slightly higher than the $88 \%$ national sample). Interestingly, there are no significant patterns of difference across gender, income, and education with respect to confidence in these institutions, with two exceptions. Those in the highest income bracket are more likely to have confidence in corporations, and those with the least education are more likely to have confidence in the media.

\section{Fig. 9: Most Important Problem Facing New Hampshire}

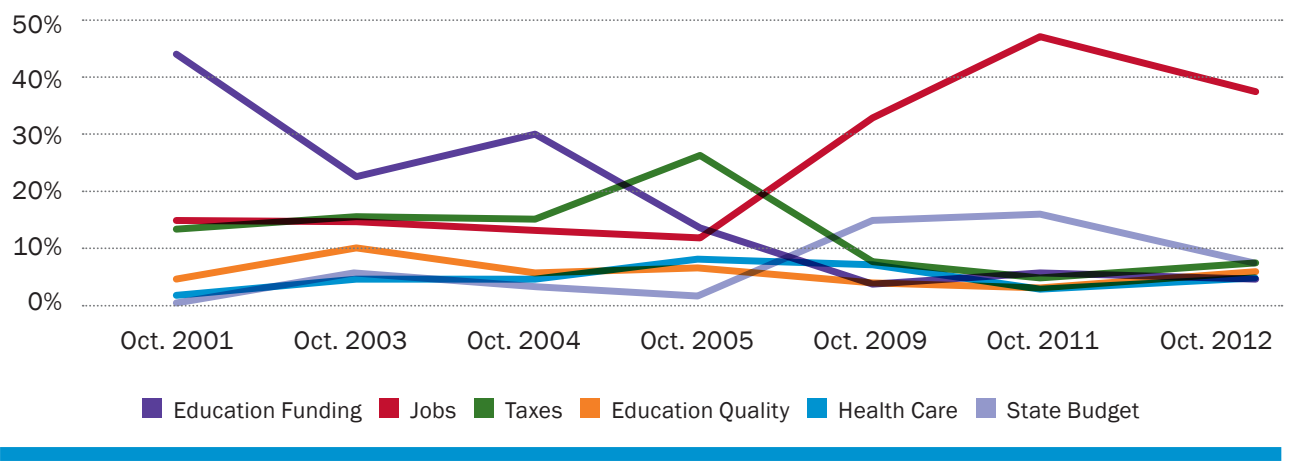

Another view of New Hampshire residents' perceptions of institutions and the overall functioning of the state comes from recent Granite State Poll data. ${ }^{69}$ Consistently since 2001, survey respondents have been asked two questions relevant to our understanding of civic health. Figure 9 shows that our greatest concern about New Hampshire since the third quarter of 2007, when the Great Recession began, has been about jobs and the economy, increasing from about 10-15\% of respondents in earlier years to almost 50\% in recent years (the rate was 38\% in October 2012). Concerns about the state budget showed a similar pattern associated with the Great Recession, going from virtually $0 \%$ to nearly $20 \%$ in the same time period (retreating back to rates less than $10 \%$ in 2012). Concern about funding for public education has declined markedly since 2001 ,

\section{$56 \%$}

of respondents believed the state is headed in the right direction in 2012, down from a high of nearly $80 \%$ in 2005 .

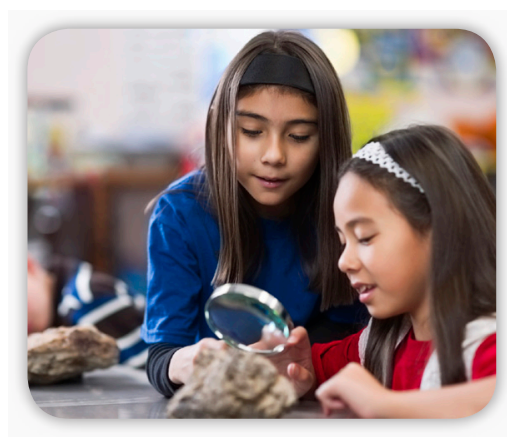


and other topics show similar declines in the level of concern, due apparently to the overriding focus on jobs and the economy. Over the same time period, survey respondents have generally believed that New Hampshire is "heading in the right direction" (see Figure 10). We seem to have experienced a bout of particular optimism around 2005 , when nearly $80 \%$ felt positive about our overall direction. By late 2012, 56\% of respondents believed we are heading in the right direction, while 33\% believed we are "on the wrong track" (with 11\% unsure). The view that we are going in the right direction is held about equally by Republicans (57\%), Democrats (56\%), and Independents (52\%). To the extent these views tell us something about our confidence in ourselves and our public institutions, we see further evidence that New Hampshire residents have a fairly robust sense that we are functioning effectively and the organizations we entrust to provide jobs, education, and information are capable of doing so. These views are not, for the most part, specific to political identity or other individual differences.

\section{Fig. 10: New Hampshire Heading in Right Direction or On Wrong Track}

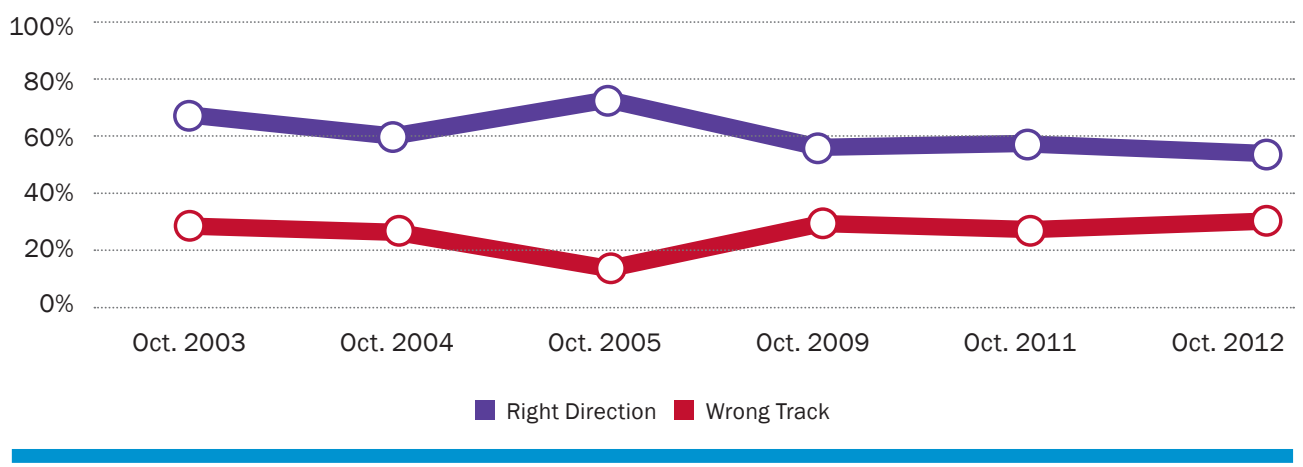

\section{CONCLUDING SUMMARY}

The data discussed in the preceding sections are indicative of a state that is in good civic health. New Hampshire has experienced some unprecedented demographic changes over the past decade, and we have been subject to the vagaries of the national economy and shifts in political majorities at both the state and national level. These pressures have not (yet) changed the fundamental social and civic nature of the state. New Hampshire residents by and large are active participants in civic life. We volunteer our time and expertise at relatively high rates, we help our neighbors, we spend time with friends and family, we are more likely to vote and engage in political conversations and activities than our national peers, and we generally trust our public and private institutions. While changes in the survey instruments used between 2008-9 and 2011-12 make many direct comparisons difficult, there do not appear to be significant shifts in civic behavior over the past few years. Changes in political activity that do appear are most likely related to the fact that 2008 was a national presidential election year, when political activity is always particularly high in New Hampshire, and data from 2010 reflect a mid-term election year, when participation rates are predictably lower. An upward trend worth noting is that more people are making charitable contributions (up four points in the last few years). This change exceeds the margin of error for the CPS.

The 2012 New Hampshire Civic Health Index demonstrates that there are two key factors that influence civic health. First, and most powerful, is the education level of our residents. Education level is strongly correlated with income and professional status. Therefore, we can use education as an inclusive variable that incorporates (or is a proxy for) professional status. The high levels of educational attainment of New Hampshire residents are associated with increased likelihood of volunteering, charitable giving, voting, engaging in political discussions, serving in civic leadership roles, attending public meetings, and contacting a public official to express an opinion or seek help. All of these activities are necessary to a healthy civic life. There is reason to believe that this is part of a virtuous cycle, in which a strong civic sector becomes self-reinforcing, creating expectations 
and aspirations for continued high levels of education and participation. Threats to that cycle have been present and will occur again. These threats include economic downturns and controversies over how to fund K-12 and higher education. Deep political division at the national, and sometimes local, level also could alter this cycle. As New Hampshire changes demographically, it will face challenges and opportunities associated with engaging residents from non-English speaking and other minority cultures, many of whom are in lower income groups than the historical population.

The second significant factor associated with strong civic health is the economic condition of the state. As discussed previously, the link between economic well-being, especially levels of employment, and civic health is clear. Education and economic well-being are closely correlated, so there is a sort of "trifecta" in New Hampshire, in which relatively high levels of education, economic productivity, and civic activity are all evident. In the past decade, New Hampshire has consistently experienced low unemployment rates (compared with national figures) and high concentrations of employment in professional and business services as well as educational and health services. The state also relies less on manufacturing and construction jobs, both of which were affected significantly by the Great Recession. ${ }^{70}$ Furthermore, the well-paying jobs in these sectors that have grown since 2000 are projected to increase at rapid rates over the next several years, constituting about a third of the labor force by $2018 .^{71}$

However, there are some signs of threat to these overall healthy trends. For example, participation in the labor force in New Hampshire declined from a high of $73 \%$ at the beginning of the decade to less than $70 \%$ in 2011. At the same time, overall employment growth was negative, and the rate of increase in educational attainment has slowed considerably. These changes are associated with an aging population and slower in-migration, especially among those who traditionally have come here with advanced degrees and sophisticated skill sets. ${ }^{72}$ While the 2012 Civic Health Index did not uncover marked changes in New Hampshire's civic well-being since the 2009 analysis, it will be important to monitor the factors discussed throughout this report in the coming years. Recent demographic and economic shifts, while not yet dramatic, may put pressure on local communities and the state as a whole to take proactive steps to ensure the civic health of the state remains strong.

\section{WHAT ARE THE IMPLICATIONS OF THE 2012 CIVIC HEALTH INDEX FOR PUBLIC POLICIES AND CIVIC PRACTICES?}

How can the generally healthy state of New Hampshire's civic life be sustained and strengthened in the future? How might we address those areas where we are less healthy compared to other states, in order to continue to attract well-educated and younger newcomers who will be our community and public leaders of tomorrow? Attention to public policy is one important arena, but policies at the local and state level are limited (and perhaps even limiting) tools for addressing such activities as volunteering, voter turnout, taking on leadership roles, and related components of civic life. We must also attend to the roles of nonprofit organizations, leadership networks that promote civic engagement, and the many informal ways in which we solve problems, welcome newcomers, and talk to each other about local matters. The data presented in this report point to the kinds of initiatives that follow.

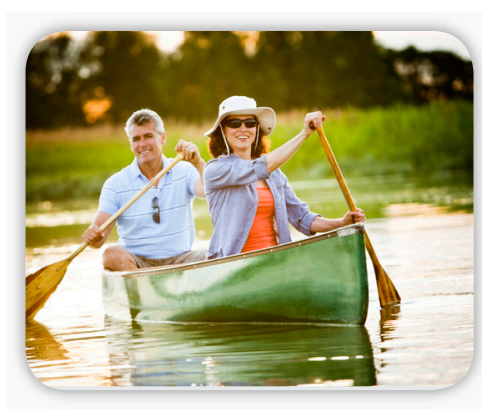




\section{Social and Economic Policy and Implications for Civic Health}

If sustaining and strengthening New Hampshire's civic health is to be a priority in the coming years, local and state policy makers - from select persons to city councilors to state representatives and senators - will want to focus on three interrelated areas that are most likely to make a difference. As this report has demonstrated, issues related to education, economy, and the state's changing demographics, have a direct impact on New Hampshire's civic health. Each of these are policy arenas in which New Hampshire has demonstrated relative strength over the years, but recent data indicate some threats to continued well-being.

\section{Education}

We have seen higher levels of educational attainment are directly correlated with higher levels of civic engagement and health. To assure the long-term health of the state, we recommend the following:

- Preserve the current rates of high school completion and increase those rates in communities that fall below the state average.

- Create incentives to increase the number of high school graduates who attend postsecondary education programs in New Hampshire (a rate that has declined in recent years); this will require attention to affordability and access to public two-year and fouryear institutions by containing the rate of increase in tuition and fees and creating more supports for high school-to-college and two-year to four-year transitions.

- Design incentives to attract students who leave New Hampshire for post-secondary education to return within five years after receiving the baccalaureate degree (for example, by offering financial aid for graduate study in state, or state loan-forgiveness programs for students who return to work in public sector jobs).

- Invest in public higher education infrastructure (such as, renewal of teaching facilities, especially in science and technology fields; expansion of online instructional resources; and access to four-year curricula in the northern-most communities).

- Address the wide range of per pupil expenditures across individual communities to create more equitable $\mathrm{K}-12$ experiences and outcomes.

- Create engaging, meaningful K-12 civics education and engagement curricula to increase the knowledge and skills of high school graduates with respect to their roles as active citizens and community leaders.

\section{Workforce development}

Linked closely to education policy, attention to workforce development is critical to both the state's civic and economic health. Here we recommend the following:

- Provide incentives to individuals and businesses for the education and training of an aging workforce that would benefit from new skills relevant to the state's professional, education, and health care sectors.

- Create targeted workforce development programs for new immigrants, including support for English-language learners, guidance and financial incentives for small and family-owned businesses, and access to capital through innovative, sustainable microenterprise programs.

- Concentrate especially on both newly arrived and displaced workers in the North Country (for example, those who have recently come to New Hampshire to work in the federal prison in Berlin, as well as millworkers and others affected by the declining timber industry). Regional approaches that include Vermont and Maine will be necessary, as will attention to the transportation infrastructure to make commuting affordable and feasible. 


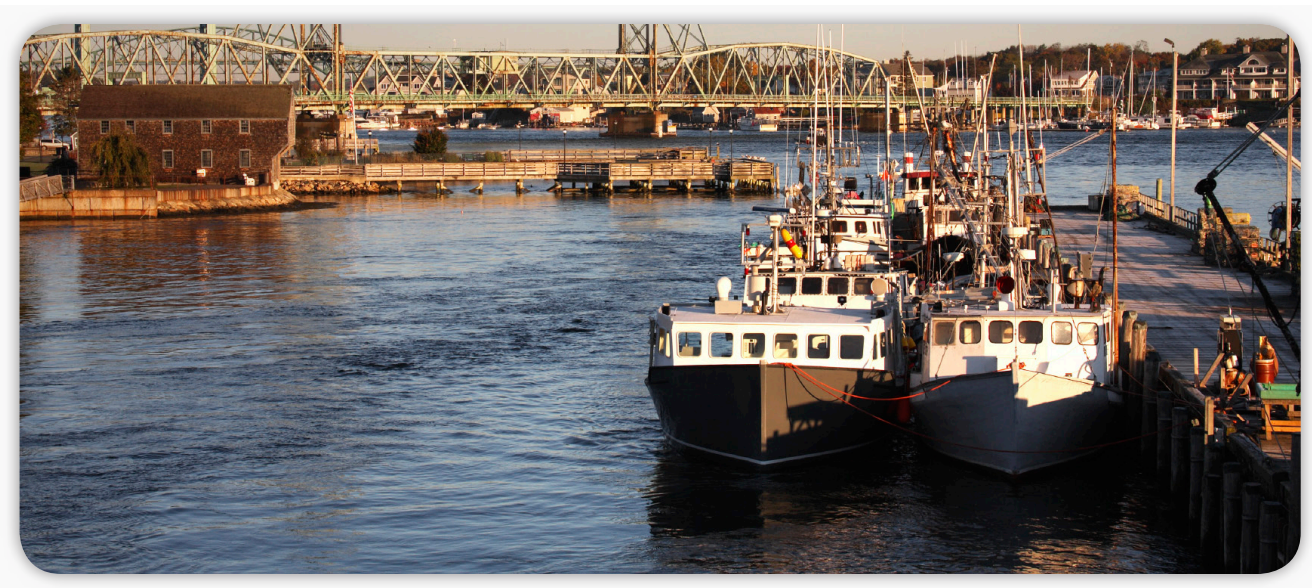

- Work with federal and private sector partners to assure that the implementation of the Affordable Care Act does not increase the cost of health care insurance at a rate greater than growth in the regional CPI. The viability of small businesses and the growth of jobs that offer adequate benefits for working families are essential for sustained economic well-being of New Hampshire communities, which in turn will contribute to our civic health.

\section{Support for an aging population and low-income families}

Increases in recent years in the numbers of children living in poverty, combined with our aging population and the persistence of recession-like conditions in the North Country, suggest the need for attention to social policies intended to increase economic opportunity, strengthen pathways to civic engagement, and to protect the most vulnerable residents of the state.

- Stimulating the development of high-quality day care and early-education programs to support working families and help young children succeed in school, especially those from families living below $150 \%$ of the poverty level.

- Assuring accessible and affordable preventive health care in all parts of the state, especially those regions that are currently underserved by pediatricians and family practitioners.

- Assuring access to work that includes a living wage and benefits necessary to keep families who have been displaced by economic shifts from falling below the poverty level.

\section{Civic Practice}

At least as important as formal policy measures, informal efforts to bolster civic life and well-being will be critical to maintaining our strong civic health. State policies are less likely to respond to the local and regional variations that characterize New Hampshire, and efforts in the civic and public sectors, driven largely by volunteers, can ensure sustained civic health even when legislators or governors turn over. In this light, we think the following areas require close attention by civic, business, and philanthropic leaders:

Programs, public education campaigns, and incentives to ensure vibrant civic participation, especially for youth and the elderly

The high rates of engagement seen in high school students need to be sustained in the early adult years, through the kinds of efforts found in Stay Work Play New Hampshire and the Young Professionals Network that it sponsors. ${ }^{73}$ The valuable experience and high levels of education found in senior citizens can be an important asset to community life. Engaging seniors in volunteer, civic, and political organizations can help to sustain their productive engagement in local communities. Emphasis on intergenerational mentoring programs and partnerships may accomplish goals of engaging both youth and the elderly in their communities and with each other. 


\section{Leadership development programs, especially for low- and middle-income groups}

Such programs can help to sustain high levels of volunteering and engagement by all New Hampshire residents, not just the wealthiest and most educated. Efforts to grow and renew local leadership will be critical to preserving our civic health. Focused, intensive programs, such as Leadership $\mathrm{NH}^{74}$ and the half-dozen regional Leadership programs, have proven to be successful, but these reach limited numbers of residents, and often tap those who have already shown leadership potential. A re-invigorated civics education curriculum in public schools, community colleges, and four-year colleges and universities will reach larger numbers of young people. The New Hampshire Institute for Civics Education and Constitutionally Speaking are two related initiatives launched over the past two years that are likely to foster this goal considerably. ${ }^{75}$ Additional efforts are necessary aimed at helping the many citizen volunteers who serve on local elective and appointed boards to carry out their public leadership roles and engage fellow citizens in constructive deliberation on local, regional, and state issues.

\section{Welcoming newcomers to the state}

Planned, concrete efforts to welcome both out-of-state and foreign immigrants can help to ensure they "take on" the civic characteristics of our longer-time residents. It will be important to integrate those who come to New Hampshire from other states, and especially from other countries where English is not the native language, into our civic and volunteer networks. As has been shown, many of these newcomers bring higher levels of education than the native population. Ethnic, linguistic, religious, and cultural differences among those who come from "away" must not become barriers to full participation in civic and public life. A study published in 2007 suggesting that more diverse communities may have less civic engagement than more homogeneous communities ${ }^{76}$ presents challenges to a state like New Hampshire as we make the transition from a traditionally white, Anglo culture to a more diverse population. Thus, targeted and sustained efforts to strengthen our increasingly diverse communities, especially in Manchester and Nashua, would seem to be of paramount importance.

\section{Civic health, like physical and mental health, requires vigorous and consistent exercise}

In order to sustain the civic health of New Hampshire, we must attend to erosion of civic life due to factors such as the hectic pace of working families, popularity of social media over faceto-face connections, loss of central public squares to shopping malls and box stores, and the disenchantment of the public with electoral politics. If we are to preserve the delicate balance between autonomy and independence on one hand, and community and collective action on the other, we must make available effective processes and inviting venues where we can exercise our civic muscles.

In recent years, several resources have begun to provide such processes and venues. The New Hampshire Humanities Council has played an important role in fostering public conversations on religion, immigration, and our rich cultural heritage. The Cooperative Extension Service at the University of New Hampshire has helped scores of communities envision and plan for their future through participatory "community profile" projects. Community theater, public art, and historical preservation efforts at the local level have helped to create shared experiences that foster trust, communication, and civic pride. Since 2011, NH Listens, a civic engagement initiative of the Carsey Institute, has helped to build local, regional, and statewide capacity for inclusive public deliberation on a range of challenges including public education, downtown revitalization, transportation and mobility, water resources, and climate adaptation.

In 2012, the New Hampshire Charitable Foundation significantly increased its attention to civic engagement and has begun funding programs such as NH Listens and similar efforts aimed at ensuring a vital civic life. United Way organizations and Leadership NH have partnered with $\mathrm{NH}$ Listens to train facilitators of public deliberation and build greater community capacity for sustained civic and civil dialogue. All of these efforts build on strong traditions even as they are responding to new challenges. In short, the "all hands-on-deck ethos of our people" that Governor Hassan cited in her inauguration speech is alive and well. The civic health of our state is strong. All of us have a part to play in making certain that it remains so. 


\section{TECHNICAL NOTES}

The 2009 New Hampshire Civic Health Index drew its data from surveys conducted by the National Conference on Citizenship (NCOC) in partnership with Knowledge Networks. Later in 2009, the NCoC was incorporated into the Edward M. Kennedy Serve America Act and authorized to expand the national civic health assessment in partnership with the Corporation for National and Community Service and the U.S. Census Bureau. Thus, analyses for the 2012 Civic Health Index were derived from the U.S. Census Bureau's Current Population Survey (CPS) and several of its supplements. Because of the shift in data collection, some, but not all, of the measures allow analysis across time. These comparisons depend on the similarity of question types and actual questions asked in common between 2009 and 2011 surveys. In addition, for many question types, a figure just for 2011 as an isolated year was provided in comparison with pooled data from 2009, 2010, and 2011. These three-year pooled averages reveal more about norms in the state than single-year data, which can change drastically due to extraneous factors. This report will be careful to clarify the background behind any trend data comparisons.

The CPS is conducted by the U.S. Census Bureau for the Bureau of Labor Statistics and collects national data on United States demographic, social, and economic trends. The CPS is administered by the Census Bureau using a probability selected sample of about 60,000 occupied households. Households from all 50 states and the District of Columbia are in the survey for four consecutive months, out of the sample for eight months, and then return for another four months before leaving the sample permanently. For more information on the CPS methodology, go to http://www. census.gov/cps/methodology/.

In addition to CPS questions related to labor and employment, the survey also collects information through supplements on various subjects including voting, volunteerism, and civic engagement. Supplemental questions are asked once a month, and individuals must be over age 15 to participate, though for some supplements, such as voting and civic engagement, participants must be over age 18. The 2012 New Hampshire Civic Health Index uses data from the Voting, Volunteerism, and Civic Engagement Supplements. The sample size for each of these supplements was slightly over 2,000 New Hampshire residents, though participation varied depending on the type of supplement. The margin of error (MOE) varies depending on the sample size, size of the population of interest, and how commonly or rarely a specific indicator happens. But according to our estimation, the state's estimates have MOEs of 1.5 to 3 percentage points. The approximate numbers of each supplement's sample size are listed below:

- September 2011 CPS Volunteer Supplement - 2,300 NH residents

- November 2010 CPS Voting and Registration Supplement - 2,130 NH residents

- November 2011 Civic Engagement Supplement - 2,220 NH residents 


\section{A WORD ABOUT RECOMMENDATIONS}

NCoC encourages our partners to consider how civic health data can inform dialogue and action in their communities, and to take an evidence-based approach to helping our communities and country thrive. While we encourage our partners to consider and offer specific recommendations and calls to action in our reports, we are not involved in shaping these recommendations. The opinions and recommendations expressed by our partners do not necessarily reflect those of the organization.

\section{ENDNOTES}

1 Governor's Commission on New Hampshire in the 21st Century (1991), New Hampshire: My Responsibility, Final Report.

2 Children's Alliance of New Hampshire, NH Kids Count Data Book 2010/2011, http://www. childrennh.org/web/Kids\%20Count/nh_whole\%20book.pdf.

3 D.R. Barrick, D.C. Delay, and S.A. Norton, From Tailwind to Headwind: New Hampshire's Shifting Economic Trends, New Hampshire Center for Public Policy Studies, September 2012, http://www.nhpolicy.org/reports/new_hampshire_new_reality_2012_final1.pdf. S.A. Norton, D.R. Barrick, D.C. Delay, and D. Lautenschlager, What Is New Hampshire? New Hampshire Center for Public Policy Studies, September 2012, http://www.nhpolicy.org/ reports/winh2012_final.pdf.

4 K.M. Johnson, New Hampshire Demographic Trends in the 21st Century, Carsey Institute, 2012, 17, http://www.carseyinstitute.unh.edu/publications/Report-Johnson-DemographicTrends-NH-21st-Century.pdf.

5 Johnson, New Hampshire Demographic Trends in the 21st Century, http://www. carseyinstitute.unh.edu/publications/Report-Johnson-Demographic-Trends-NH-21stCentury.pdf.

6 The Annie E. Casey Foundation, Kids Count Databook: State Trends in Child Well-being, 2012, http://www.aecf.org/ /media/Pubs/Initiatives/KIDS\%20 COUNT/123/2012KIDSCOUNTDataBook/KIDSCOUNT2012DataBookFullReport.pdf.

7 The Annie E. Casey Foundation, Kids Count Data Center, Data Across States, http:// datacenter.kidscount.org/data/acrossstates/Rankings. aspx?loct=2\&by=a\&order=a\&ind $=4$ $3 \& \mathrm{dtm}=322 \& \mathrm{tf}=16$

8 Norton, Barrick, Delay, and Lautenschlager, What is New Hampshire?, http://www.nhpolicy. org/reports/winh2012_final.pdf.

9 Johnson, New Hampshire Demographic Trends in the 21st Century, 13, http://www carseyinstitute.unh.edu/publications/Report-Johnson-Demographic-Trends-NH-21stCentury.pdf.

10 Johnson, New Hampshire Demographic Trends in the 21st Century, http://www. carseyinstitute.unh.edu/publications/Report-Johnson-Demographic-Trends-NH-21stCentury.pdf.

11 Barrick, Delay, and Norton, From Tailwind to Headwind: New Hampshire's Shifting Economic Trends, 3-4, http://www.nhpolicy.org/reports/new_hampshire_new_reality_2012_final1. pdf.

12 Johnson, New Hampshire Demographic Trends in the 21st Century, 5, http://www. carseyinstitute.unh.edu/publications/Report-Johnson-Demographic-Trends-NH-21stCentury.pdf.

13 Norton, Barrick, Delay, and Lautenschlager, What is New Hampshire?, http://www.nhpolicy. org/reports/winh2012_final.pdf.

14 The relative high proportion of women serving in public office in New Hampshire is further exemplified by the 2012 election results, which produced the first all-female Congressional delegation in U.S. history, complemented by the election of New Hampshire's second woman governor. From K. Seelye, "From Congress to Halls of State, in New Hampshire, Women Rule," The New York Times, January 1, 2013

15 One-third of all NH towns still conducted business via the traditional annual town meeting in 2011. Norton, Barrick, Delay, and Lautenschlager, What is New Hampshire?, http://www. nhpolicy.org/reports/winh2012_final.pdf.

${ }_{16}$ Party registration is a distinct measure from party identification, with the latter more likely to predict actual voting behavior than the former. When asked party identification, about $18 \%$ of $\mathrm{NH}$ voters respond "independent." Personal communication from Andy Smith, director of UNH Survey Center, January 27, 2013.

17 Election Results 2008, The New York Times, December 9, 2008, http://elections.nytimes. com/2008/results/states/new-hampshire.html.

18 Election 2010, The New York Times, http://elections.nytimes.com/2010/results/newhampshire.

19 Statistics based on author tabulation of 2010 data from the New Hampshire Secretary of State, http://sos.nh.gov/ElectResults.aspx.

20 "President: New Hampshire," CNN, http://www.cnn.com/election/2012/results/state/NH/ president

21 New Hampshire Congressional Delegation, http://www.nh.gov/government/nhcong.html.

22 U.S. Senators of the 113th Congress, http://www.senate.gov/general/contact_information/ senators_cfm.cfm?State $=\mathrm{NH}$.

23 "Our Mission," Free State Project, accessed February 19, 2013, http://freestateproject. org/intro.

24 "Choose New Hampshire, Where Freedom Happens First," Free State Project, accessed on February 19, 2013, http://freestateproject.org/choosenh. "101 Reasons You Should Move to New Hampshire (If You Love Liberty)," Free State Project, accessed on February 19 2013, http://freestateproject.org/101Reasons

25 "Educational attainment is strongly correlated to all types of political and civic engagement," Ohio Civic Health Index, National Conference on Citizenship, November 8, 2010, http://ncoc.net/Educational_Attainment_is_Strongly_Correlated_to_All_Types_of_ Political_and_Civic_Engagement.

26 Status of higher education in New Hampshire (May 2009-2012), NH Department of Education, Division of Higher Education, Higher Education Division, http://www.education. nh.gov/highered/research/documents/2012_status_report.pdf.

${ }_{27}$ Barrick, Delay, and Norton, From Tailwind to Headwind: New Hampshire's Shifting Economic Trends, 6-7, http://www.nhpolicy.org/reports/new_hampshire_new reality_2012_final1.pdf. 
28 Johnson, New Hampshire Demographic Trends in the 21st Century, 17, http://www. carseyinstitute.unh.edu/publications/Report-Johnson-Demographic-Trends-NH-21stCentury.pdf.

29 Norton, Barrick, Delay, and Lautenschlager, What is New Hampshire?, http://www.nhpolicy. org/reports/winh2012_final.pdf.

3o Johnson, New Hampshire Demographic Trends in the 21st Century, 18, http://www. carseyinstitute.unh.edu/publications/Report-Johnson-Demographic-Trends-NH-21stCentury.pdf.

31 List of New Hampshire Institutions, The Project on Student Debt, The Institute for College Access and Success, accessed January 8, 2013, http://projectonstudentdebt.org/state by_state-view2012.php?area= $\mathrm{NH}$.

32 S. Cohn, "Student loan debt hits record high, study shows," NBC News, October 18, 2012, http://www.nbcnews.com/business/student-loan-debt-hits-record-high-study-shows$1 \mathrm{C} 6542975$.

$3 з$ K. Stokes, "Indiana student loan default rate tops all but two other states," National Public Radio, October 19, 2011, http://stateimpact.npr.org/indiana/2011/10/19/indianastudent-loan-default-rate-tops-all-but-two-other-states/.

34 New Hampshire Public Schools by District Number, New Hampshire Department of Education, accessed January 22, 2013, http://my.doe.nh.gov/Profiles/PublicReports/ PublicReports.aspx?ReportName=SchoolList.

35 Norton, Barrick, Delay, and Lautenschlager, What is New Hampshire?, 66, http://www. nhpolicy.org/reports/winh2012_final.pdf.

${ }_{36}$ Norton, Barrick, Delay, and Lautenschlager, What is New Hampshire?, 67, http://www. nhpolicy.org/reports/winh2012_final.pdf.

${ }_{37}$ Cost Per Pupil by District 2011-2012, New Hampshire Department of Education, http:// www.education.nh.gov/data/documents/cost_pup11_12.pdf.

$38 \mathrm{NH}$ has $12 \%$ of children living in poverty, compared with a national rate of $23 \%$. Kids Count Databook: State Trends in Child Well-being, http://www.aecf.org/ /media/Pubs/Initiatives/ KIDS\%20COUNT/123/2012KIDSCOUNTDataBook/KIDSCOUNT2012DataBookFullReport. pdf.

39 Free and Reduced Lunch School Eligibility, 2011-2012, NH Department of Education, February 22, 2013, http://www.education.nh.gov/data/documents/lunch_school11_12. pdf.

40 Kids Count Databook: State Trends in Child Well-being, http://www.aecf.org/ / media/Pubs/Initiatives/KIDS\%20COUNT/123/2012KIDSCOUNTDataBook/ KIDSCOUNT2012DataBookFullReport.pdf.

41 Dropouts and Completers, New Hampshire Department of Education, accessed February 22, 2013, http://www.education.nh.gov/data/dropouts.htm. Norton, Barrick, Delay, and Lautenschlager, What is New Hampshire?, 74, http://www.nhpolicy.org/reports/winh2012 final.pdf.

42 National dropout rates are $7.4 \%$ for 2010, From "Fast Facts," National Center for Educational Statistics, Institute of Educational Sciences, http://nces.ed.gov/fastfacts/ display.asp?id=16 and Indicators of New Hampshire Youth Well-being, Children's Alliance of New Hampshire, http://www.childrennh.org/web/PDF/NH Youth Well Being Indicators Brief FINAL.pdf.

43 Manchester school district's four-year cumulative drop-out rate is $11.25 \%$. Dropouts and Completers, New Hampshire Department of Education, accessed February 22, 2013 http://www.education.nh.gov/data/dropouts.htm.

44 New Hampshire data from 2011 Youth Risk Behavior Survey Results, Center for Disease Control and Prevention, http://www.education.nh.gov/instruction/school_health/documen ts/2011nhyrbsresultsgraphs.pdf; U.S. data from Youth Risk Behavior Surveillance: United States, 2011, Surveillance Summaries: Morbidity and Mortality Weekly Report, 61 (June 8 2012): 4, http://www.cdc.gov/mmwr/pdf/ss/ss6104.pdf.

452011 Youth Risk Behavior Survey Results, http://www.education.nh.gov/instruction/ school_health/documents/2011nhyrbsresultsgraphs.pdf, and Youth Risk Behavior Surveillance: United States, 2011, http://www.cdc.gov/mmwr/pdf/ss/ss6104.pdf.

46 Youth Online: High school YRBS, New Hampshire 2011 and United States 2011 Results, Center for Disease Control and Prevention, http://apps.nccd.cdc.gov/youthonline/App/ Default.aspx.

47 Youth Online: High school YRBS, New Hampshire 2011 and United States 2011 Results, http://apps.nccd.cdc.gov/youthonline/App/Default.aspx.

48 New Hampshire Economic Review 2012 Press Release, Prospernh.com and Public Service of New Hampshire, NH Employment Security, http://www.nhes.nh.gov/elmi/statistics/ documents/nr-current.pdf.

49 Barrick, Delay, and Norton, From Tailwind to Headwind: New Hampshire's Shifting Economic Trends, 5-6, http://www.nhpolicy.org/reports/new_hampshire_new_reality_2012_final1. pdf.

50 Barrick, Delay, and Norton, From Tailwind to Headwind: New Hampshire's Shifting Economic Trends, 5-6, http://www.nhpolicy.org/reports/new_hampshire_new_reality_2012_final1. pdf.

51 Norton, Barrick, Delay, and Lautenschlager, What is New Hampshire?, 1, http://www. nhpolicy.org/reports/winh2012_final.pdf.

52 Barrick, Delay, and Norton, From Tailwind to Headwind: New Hampshire's Shifting Economic Trends, 2, http://www.nhpolicy.org/reports/new_hampshire_new_reality_2012_final1.pdf.

53 Barrick, Delay, and Norton, From Tailwind to Headwind: New Hampshire's Shifting Economic Trends, 9, http://www.nhpolicy.org/reports/new_hampshire_new_reality_2012_final1.pdf.
54 National Conference on Citizenship, Civic Health and Unemployment: Can Engagement Strengthen the Economy?, Washington, DC, 2011, www.ncoc.net/unemployment.

55 National Conference on Citizenship, Civic Health and Unemployment II: The Case Builds, Washington, DC, 2012, September, www.ncoc.net/unemployment2.

56 Volunteering and Civic Life in New Hampshire (2011), http://www.volunteeringinamerica. gov/NH/Customize.

57 Volunteering and Civic Life in New Hampshire (2011), http://www.volunteeringinamerica. gov/NH/Customize.

58 Income brackets as used in the report are as follows: Lower income is below $\$ 35,000 / y e a r$, middle income is $\$ 35,000-\$ 100,000$, and high income is above $\$ 100,000$. The categories were created based on the distribution of household income in New Hampshire, so that approximately one third of households fall into each of the three categories.

59 Volunteering and Civic Life in New Hampshire (2011), http://www.volunteeringinamerica. gov/NH/Customize.

60 B. Gose, "Wealthiest don't rate high on giving measure," The Chronicle of Philanthropy, August 23, 2012, B10-11, B-6, http://philanthropy.com/article/America-s-GeographicGiving/133591/

61 "How states stack up in generosity," The Chronicle of Philanthropy, August 23, 2012, B23, http://philanthropy.com/article/Sharing-the-Wealth-How-the/133605/.

62 Gose, "Wealthiest don't rate high on giving measure," B10-11, http://philanthropy.com/ article/America-s-Geographic-Giving/133591/.

63 F. Newport, "Mississippi is the most religious U.S. State." Gallup, March 27, 2012, http:// www.gallup.com/poll/153479/Mississippi-Religious-State.aspx.

64 Newport, "Mississippi is the most religious U.S. State," http://www.gallup.com/ poll/153479/Mississippi-Religious-State.aspx.

65 The NH Secretary of State defines turnout as a percent of votes cast among those who are registered, and is different from the percent of citizens in the state who voted.

${ }_{66}$ Calculations based on data from the NH Secretary of State's Office, accessed January 5, 2013, http://sos.nh.gov/ElectResults.aspx.

67 R.D. Putnam, Bowling Alone: The Collapse and Revival of American Community (New York: Simon \& Schuster, 2000)

68 Putnam, Bowling Alone: The Collapse and Revival of American Community.

69 A.E. Smith and C.S. Novak, "Economy Still Top Concern in NH, Hassan Starts Out in Positive Position," The WMUR Granite State Poll, The University of New Hampshire Survey Center, February 7, 2013, http://www.unh.edu/survey-center/news/pdf/gsp2013_winter govapp020713.pdf.

70 New Hampshire Fact Book: Labor Market, Economic and Community Development Division, Public Service of New Hampshire, August, 2011.

71 New Hampshire Fact Book: Labor Market, Economic and Community Development Division, Public Service of New Hampshire, August, 2011.

72 Barrick, Delay, and Norton, From Tailwind to Headwind: New Hampshire's Shifting Economic Trends, http://www.nhpolicy.org/reports/new_hampshire_new_reality_2012_final1.pdf.

73 “About Us," Stay, Work, Play, http://stayworkplay.org/about-us.

74 Leadership NH, http://www.leadershipnh.org/.

75 Constitutionally Speaking, http://www.constitutionallyspeakingnh.com/.

76 R.D. Putnam, "E Pluribus Unum: Diversity and Community in the Twenty-First Century," The 2006 Johan Skytte Prize Lecture, Scandinavian Political Studies, 30(2), 2007, http://www. abdn.ac.uk/sociology/notes07/Level4/S04530/Assigned-Readings/Reading\%209\%20 $\% 28$ new\%29.pdf. 


\section{CIVIC HEALTH INDEX}

\section{State and Local Partners}

NCoC began America's Civic Health Index in 2006 to measure the level of civic engagement and health of our democracy. In 2009, NCOC was incorporated into the Edward M. Kennedy Serve America Act and directed to expand this civic health assessment in partnership with the Corporation for National and Community Service and the U.S. Census Bureau.

NCOC now works with partners in more than 30 communities nationwide to use civic data to lead and inspire a public dialogue about the future of citizenship in America and to drive sustainable civic strategies.

STATES

\section{Alabama}

University of Alabama

David Mathews Center

Auburn University

\section{Arizona}

Center for the Future of Arizona

\section{California}

California Forward

Center for Civic Education

Center for Individual and

Institutional Renewal

Davenport Institute

\section{Connecticut}

Everyday Democracy

Secretary of the State of Connecticut

\section{Florida}

Florida Joint Center for Citizenship Bob Graham Center for Public Service Lou Frey Institute of Politics and Government

John S. and James L. Knight Foundation

\section{Georgia}

GeorgiaForward

Carl Vinson Institute of Government,

The University of Georgia

Georgia Family Connection Partnership

Illinois

Citizen Advocacy Center

McCormick Foundation

CITIES

Chicago
McCormick Foundation

Miami

Florida Joint Center for Citizenship

John S. and James L. Knight Foundation

Miami Foundation

\section{Seattle}

Seattle City Club

Boeing Company

Seattle Foundation

\section{Indiana}

Center on Congress at Indiana University

Hoosier State Press

Association Foundation

Indiana Bar Foundation

Indiana Supreme Court

Indiana University Northwest

\section{Kentucky}

Commonwealth of Kentucky,

Secretary of State's Office

Institute for Citizenship \& Social Responsibility,

Western Kentucky University

Kentucky Advocates for Civic Education

McConnell Center, University of Louisville

\section{Maryland}

Mannakee Circle Group

Center for Civic Education

Common Cause-Maryland

Maryland Civic Literacy Commission

\section{Massachusetts}

Harvard Institute of Politics

\section{Michigan}

Michigan Nonprofit Association

Michigan Campus Compact

\section{Minnesota}

Center for Democracy and Citizenship

\section{Missouri}

Missouri State University

\section{New Hampshire}

Carsey Institute

\section{Twin Cities}

Center for Democracy and Citizenship Citizens League

John S. and James L. Knight Foundation

\section{New York}

Siena College Research Institute New York State Commission on National and Community Service

North Carolina

North Carolina Civic

Education Consortium

Center for Civic Education

NC Center for Voter Education

Democracy NC

NC Campus Compact

Western Carolina University Department of Public Policy

Ohio

Miami University Hamilton Center for Civic Engagement

\section{Oklahoma}

University of Central Oklahoma

Oklahoma Campus Compact

\section{Pennsylvania}

Center for Democratic Deliberation National Constitution Center

\section{Texas}

University of Texas at San Antonio

\section{Virginia}

Center for the Constitution at James

Madison's Montpelier

Colonial Williamsburg Foundation

MILLENNIALS CIVIC HEALTH INDEX

Mobilize.org

Harvard Institute of Politics

CIRCLE 


\section{Justin Bibb}

Special Assistant for Education and Economic Development for the County Executive, Cuyahoga County, Ohio

\section{Harry Boyte}

Director, Center for Democracy

and Citizenship

\section{John Bridgeland}

CEO, Civic Enterprises

Chairman, Board of Advisors, National

Conference on Citizenship

Former Assistant to the President of the

United States \& Director, Domestic Policy

Council \& USA Freedom Corps

\section{Nelda Brown}

Executive Director, National Service-

Learning Partnership at the Academy for Educational Development

\section{Kristen Cambell}

Chief Program Officer,

National Conference on Citizenship

\section{Jeff Coates}

Strategic Initiatives Associate, John S. and James L. Knight Foundation

\section{Doug Dobson}

Executive Director,

Florida Joint Center for Citizenship

\section{David Eisner}

Former President and CEO,

National Constitution Center

\section{Paula Ellis}

Vice President, Strategic Initiatives, John S. and James L. Knight Foundation

\section{Maya Enista Smith}

Former CEO, Mobilize.org

\section{William Galston}

Senior Fellow, Brookings Institution Former Deputy Assistant to the President of the United States for Domestic Policy

\section{Stephen Goldsmith}

Former Deputy Mayor of New York City Daniel Paul Professor of Government, Kennedy School of Government at Harvard University

Director, Innovations in American

Government

Former Mayor of Indianapolis

\section{Robert Grimm, Jr.}

Director of the Center for Philanthropy and Nonprofit Leadership, University of Maryland

\section{Lloyd Johnston}

Research Professor and Distinguished Research Scientist at the University of Michigan's Institute for Social Research Principal Investigator of the Monitoring the Future Study

\section{Kei Kawashima-Ginsberg}

Lead Researcher, Center for Information and Research on Civic Learning and Engagement (CIRCLE) at the Jonathan M. Tisch College of Citizenship and Public Service at Tufts University

\section{Peter Levine}

Director, Center for Information and Research on Civic Learning and Engagement (CIRCLE) at the Jonathan M. Tisch College of Citizenship and Public Service at Tufts University

\section{Chaeyoon Lim}

Assistant Professor of Sociology,

University of Wisconsin-Madison

\section{Mark Hugo Lopez}

Associate Director of the

Pew Hispanic Center

Research Professor, University of

Maryland's School of Public Affairs

\section{Sean Parker}

Co-Founder and Chairman of Causes on Facebook/MySpace

Founding President of Facebook

\section{Kenneth Prewitt}

Former Director of the United States

Census Bureau

Carnegie Professor of Public Affairs and the Vice-President for Global Centers at Columbia University

\section{Robert Putnam}

Peter and Isabel Malkin Professor of Public Policy, Kennedy School of Government at Harvard University Founder, Saguaro Seminar

Author of Bowling Alone: The Collapse and Revival of American Community

\section{Thomas Sander}

Executive Director, the Saguaro Seminar, Harvard University

\section{David B. Smith}

Chief of Programs and Strategy, National Center for Service and Innovative Leadership

Founder, Mobilize.org

\section{Heather Smith}

Executive Director, Rock the Vote

\section{Max Stier}

Executive Director, Partnership for Public Service

\section{Michael Stout}

Associate Professor of Sociology, Missouri State University

\section{Kristi Tate}

Director of Community Strategies, National Conference on Citizenship

\section{Michael Weiser}

Chairman, National Conference on Citizenship

\section{Jonathan Zaff}

Vice President for Research, America's Promise Alliance

\section{Ilir Zherka}

Executive Director, National Conference on Citizenship 


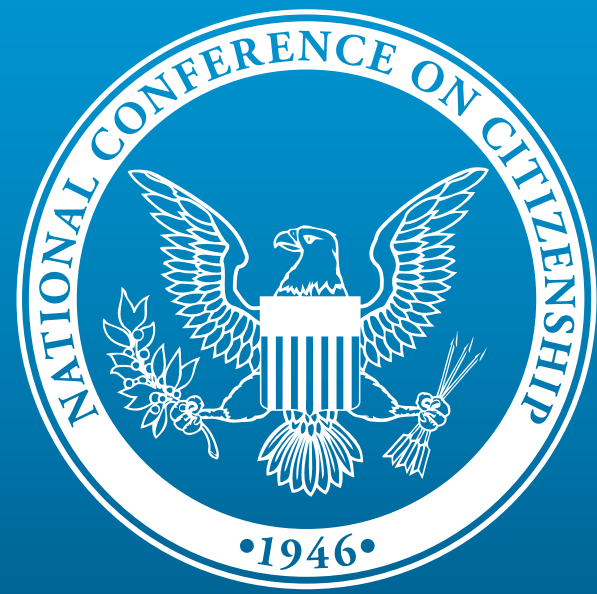

NCoC

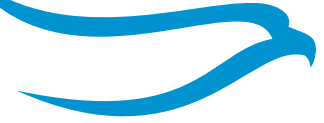

National Conference on Citizenship Chartered by Congress

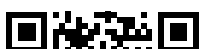 \\ Qherting \\ . \\ .

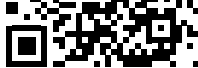

Use your smart phone to download the New Hampshire Civic Health Index

\section{CARSEY I N S T I T U T E \\ ATTHE UNIVERSITY OF NEW HAMPSHIRE}

University System of New Hampshire

New Hampshire College

UNIVERSITY

Council

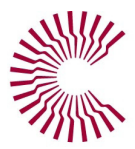

Campus Compact for New Hampshire 